\title{
Research into balance of rocks and underground cavities formation in the coal mine flowsheet when mining thin seams
}

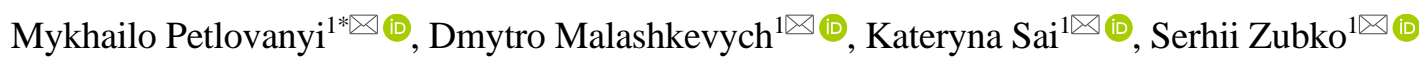 \\ ${ }^{1}$ Dnipro University of Technology, Dnipro, 49005, Ukraine \\ *Corresponding author: e-mail petlyovanyi1986@gmail.com, tel. +380963194577
}

\begin{abstract}
Purpose. Study the movement of waste rock flows in the coal mine technological system and determine the balance of rocks and underground cavities formation from the perspective of the current mining operations development in order to assess the possibility of leaving the rock in the underground area.

Methods. Based on the rank order of the Western Donbass mines, a coal mine has been chosen as the object of research in terms of maximum output and ash content. An algorithm is proposed for analytical studies of determining the rock outcrop in the course of stope, drifting and repair operations, as well as the prospective volumes of underground cavities for placing the formed waste rocks per a calendar year. The algorithm is based on the actual state of mining operations and the indicators of the stope and drifting faces of the mine, as well as the achieved modern mining-engineering parameters of the coal seams mining.
\end{abstract}

Findings. It has been revealed that the main supply of waste rocks to the surface occurs as a result of stope operations with rock undercut $-39 \%$ and underground mine workings - 33\%. It is proposed to differentiate all waste rock outcropped after mining operations into 2 categories: difficult to dispose of and prospective for disposal. It has been found that underground cavities have enormous potential for stockpiling of all waste rocks, the volume of which is by $2.8-4.8$ times higher than the rock volume. It has been revealed that the most rational balance of waste rocks and cavities for leaving the rock in the mine is formed along the $\mathrm{C}_{10}{ }^{\mathrm{t}}$ seam. It has been determined that the full-fledged placement of rocks is limited by the scheduling peculiarities of mining the reserves along the seams, which are made for the complete cave-in technology of coal mining.

Originality. For the first time, for one of the Western Donbass mines, the balance of formed waste rocks and potential underground cavities, dynamically changing in time and space, has been determined.

Practical implications. The results obtained are useful for engineering new spatial planning solutions for the optimal development of mining operations with the maximum possible rocks stockpiling in the underground area of mines.

Keywords: waste rocks, ash content, underground cavities, undercut, stope and drifting face, backfill, scheduling

\section{Introduction}

Ukraine is among the countries where a significant part of the economy is based on the mineral-raw resources development [1]-[3]. The iron ore and coal industries are of great importance to the country [4]-[6]. The iron ore industry, through taxes and exports, provides revenues to the budget in the amount of 2.9 billion dollars, the coal industry plays an important role in ensuring energy independence $-1 / 3$ of all the generated energy is provided by burning coal at thermal power plants (TPP). Most of the Ukrainian TPPs are equipped with everything necessary for energy generation using the $G$ grade (gas) coal, which indicates the priority of this type of coal for society and the economy. Despite the current priority of generating electricity from renewable sources, the share of coal in the global energy balance remains significant - 36\% [7]-[10] and, according to ex- perts [11]-[13], it will occupy this key position for a long period of time. Development of alternative energy sources is also considered in the future [14]-[16].

Potentially mined bituminous coal reserves amount to over 33 billion tonnes, but 27 billion tons, or $80 \%$ of coal reserves, are concentrated in seams less than $1.0 \mathrm{~m}$ thick [17]-[19]. The development of thin coal seams is accompanied by significant operating expenditures in the mining process, as a result of which high production cost figures are formed. Therefore, for the development of these reservoirs in the world, in addition to traditional technologies, geotechnological mining methods are also used, such as underground gasification [20], [21]. Otherwise, these seams are referred to unpromising and are not subject to commercial development.

When mining the medium-thickness seams and highthickness seams, to prevent the earth's surface deformations 
after the valuable reserves development (especially under protected objects), as well as to improve the ecological situation, mining technologies with backfilling of mined-out area are used [22]-[24]. At the same time, in the world, the seams with a geological thickness of less than $1.0 \mathrm{~m}$ are not commercially developed due to the classification of such seams as non-commercial, and in Ukraine such seams are developed commercially, but there are no backfilling technologies under given conditions [25]. Backfilling of the mined-out area leads to reducing the stress in the rock mass and minimizes the surface subsidence [26]-[28].

Forced waste rocks undercutting in the process of stope operations forms an unproductive waste rock movement in the mining flowsheet. Thus, instead of transporting coal with a minimum natural ash content (10-15\%), there is a technological need to transport these rocks along the conveyor system of a coal mine: to load additionally the mine skip winding, transport this rock mass to the processing plant and, after the beneficiation process, supplement the existing mine waste dumps with separated coarse rocks, which leads to new automobile transport costs.

Significant waste generation is also formed as a result of underground mining operations. As a result, waste accumulations in the form of waste rock dumps, which occupy about 7 thousand hectares, are formed on the surface [29], [30]. Today, when mining 1000 tons of coal, the waste rock yield is 500 tons. Along with the negative consequences of stockpiling the rock on the surface, its delivery from the mine requires the diversion of certain lifting equipment capacity. The waste rock accumulation occupies valuable agricultural lands, leading to environmental pollution, and requires the owner to pay an environmental tax for the storage of each 1 ton of waste [31], [32]. When mining ore deposits, backfill- ing technologies are used [33], [34] in which rocks are successfully utilized from the surface rock dump, and when mining coal deposits, surface rock dumps are replenished annually [35], [36].

The problematic aspects of mining the coal seams raise the urgent issue of a radical revision of traditional technologies and existing approaches to coal mining, as well as creation of new low-waste technologies, having a higher level of economic and environmental mining efficiency. However, for this purpose, the balance of the formed rocks and underground cavities in the coal mine flowsheet should be studied in detail.

\section{Methods}

A significant contribution to the total coal production in Ukraine is made by the coal-mining region of the Western Donbass (60\%), where 10 coal mines operate [37] (Fig. 1). The Western Donbass mines in terms of output, technicaland-economic indicators and investments in production significantly exceed the level of state-owned mines. Despite the more productive performance of mines compared to the state sector, the geological conditions of mining have deteriorated significantly, and the total costs of coal extraction have increased. This is caused by the small geological thickness of the coal seams and the associated dilution of mined coal with waste rocks (ash content).

The conditions of the Western Donbass, as well as of Ukraine as a whole, are characterized by a significant predominance of coal reserves concentrated in thin seams. Not less than $87.7 \%$ of the coal reserves are concentrated in the seams less than $0.9 \mathrm{~m}$ thick, which leads to a decrease in the mined coal quality.

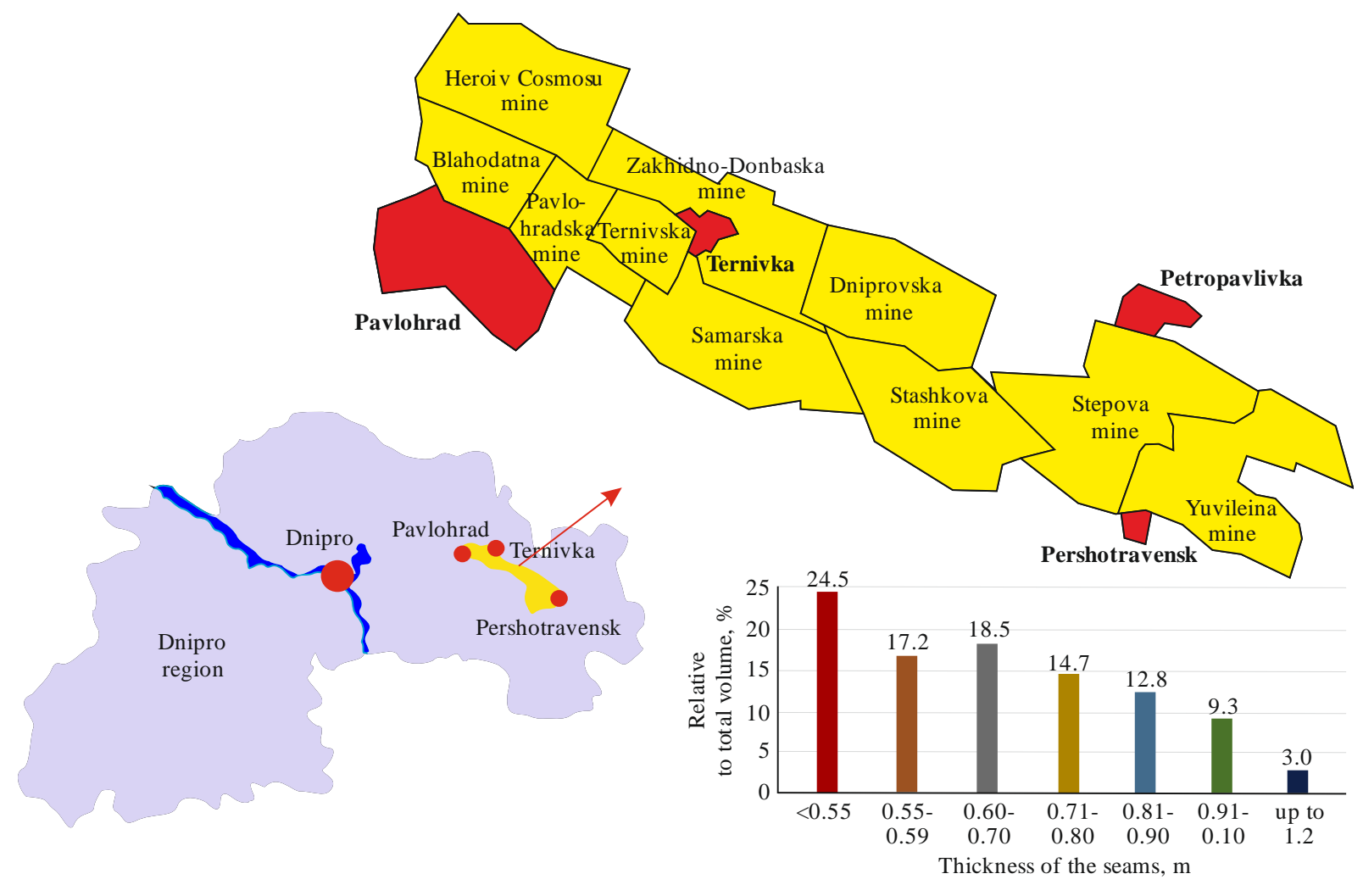

Figure 1. Layout of mine fields of PJSC "DTEK Pavlohradvuhillia" coal mines in the Western Donbass 
For example, in 2018, the average geological thickness of coal seams in the Western Donbass mines reached $0.83 \mathrm{~m}$ with an average ash content of $43 \%$. The achieved ash content level provides an additional supply of rocks to the surface in the amount of 4.0-4.5 million tons per year, in addition to rocks from mine workings. To this date, 11 waste dumps have been accumulated on the surface, where about 100 million tons of waste rock are concentrated on an area of 200 hectares [31].

The main reason for the ash content formation of coal during mining is as follows. Most of the stope faces in the PJSC "DTEK Pavlohradvuhillia" mines are equipped with domestic complexes KD-80 and KD-90, foreign powered roof supports OSTROJ and shearer-loaders UKD-200-250, UKD-200-400, UKD-200-500, UKD-300, KA-200, and MB-410E [17], [37]. These measures for the mechanization of stope operation do not allow mining of seams with a thickness of less than $1.05 \mathrm{~m}$ without undercutting the side rocks. This is conditioned by the dimensions of the mechanized complexes and the observance of the required height of free passage along the longwall face for the service personnel. Thus, for example, with an equal adopted extracting seam thickness of $1.05 \mathrm{~m}$, the value of undercutting the rocks in the stope faces when mining the $\mathrm{C}_{10}{ }^{\mathrm{t}}$ seam (Zakhidno-Donbaska mine, shearer UKD 200-250) is $0.06 \mathrm{~m}$, and during mining of the $\mathrm{C}_{11}$ seam (Heroiv Cosmosu mine, shearer KA-200) - $0.2 \mathrm{~m}$.

Based on statistical data, the average undercutting value in the faces is $0.24 \mathrm{~m}$ or $22.8 \%$ of the extracting seam thickness, and in some cases in mines it reaches 0.3-0.4 m. High undercutting value $(0.32 \mathrm{~m})$ is demonstrated in Figure 2, which shows a section drawing of one of the stope faces in the Blahodatna mine. Undercutting of the host rocks leads to mixing the broken coal with the rock and deterioration of its quality characteristics [38]-[40].

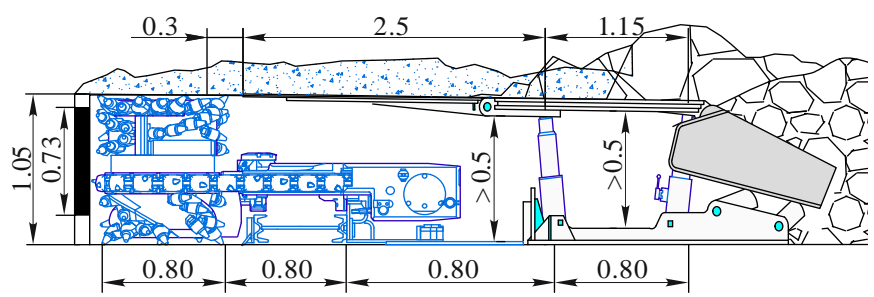

Figure 2. Cross-section of the stope face in the Blahodatna mine

Also, a significant problem of the coal reserves mining is the earth's surface subsidence, which occurs due to the formation of shift troughs [41], [42], especially when mining without backfilling the mined-out area. In the Pavlohrad Region in the vicinity of the Bohdanivka village and the town of Ternivka, as a result of undermining the territory of the Ternivska, Samarska, Zakhidno-Donbaska mines, a flooding zone with an area of about $17 \mathrm{~km}^{2}$ has been formed. Due to the subsidence of the undermined territories, the groundwater level rose, which has led to waterlogging. The depth of the groundwater level in the flooded areas ranges from 1.1 to $3.0 \mathrm{~m}$. The annual monitoring of the level of the earth surface and groundwater shows that, in comparison with 2018, the surface subsidence has increased by $0.15 \mathrm{~m}$, while there are no measures to prevent flooding [43]. According to some data, the earth's surface subsidence in the flood-plain of the Samara River reaches $7.5 \mathrm{~m}$. Similar processes tend to occur also in the course of reserves mining in other 7 mines of the Western Donbass.
To develop a progressive low-waste technology for mining the coal seams with the waste rocks stockpiled in the underground mined-out area, the following scientific objectives should be solved:

- identify the sources of formation and volumes of rock flows movement in the technological system of a coal mine;

- assess the volumes of formed underground cavities suitable for waste rock placement.

\section{Research method}

\subsection{Substantiation and selection of the research object}

To conduct a scientific-technical analysis of the rock flows movement and certain underground space areas formation, it is necessary to select a coal mine as an object of research. As a criterion, it is proposed to use a specific indicator based on the most important quantitative parameter of a mine - annual capacity. As known, a coal mine produces rock mass $\left(A_{r . m}\right)$, which is a mixture of coal and waste rock. The indicator characterizing the presence of waste rocks is called ash content. If to know the values of the mine annual capacity and the value of the mined coal ash content, a specific indicator is determined, which shows the ratio of mined cleaned coal $\left(A_{\text {coal }}\right)$ to its ash content $\left(A_{\text {ash }}\right)$, that is, to the content of waste rock. On the basis of generalization and systematization of the performance indicators from 10 coal mines of the PJSC "DTEK Pavlohradvuhillia", their rank order is given according to the ratio of mined coal to its ash content or the content of waste rocks for a stable period of their operation in recent years (Fig. 3).

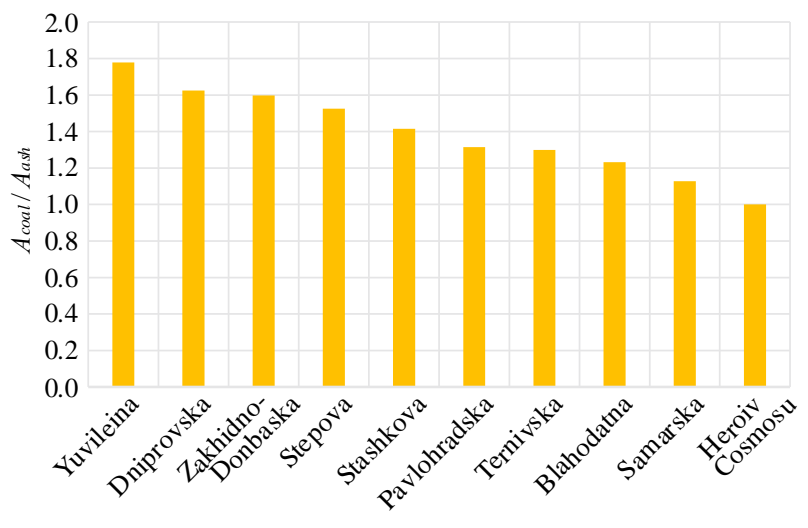

Figure 3. Rank order of the PJSC "DTEK Pavlohradvuhillia" mines according to the ratio of mined coal to its ash content

As can be seen from Figure 3, the most favourable specific indicator $A_{\text {coal }} / A_{\text {ash }}=1.8$ is observed in the Yuvileina mine, which indicates that the coal content in the mined rock mass is by 1.8 times higher than that of waste rocks. The worst specific indicator $A_{\text {coal }} / A_{\text {ash }}=1.0$ is in the Heroiv Cosmosu mine, which indicates the equal content of both coal and rocks in the mined rock mass (2.6 million tons were mined with an ash content of $50 \%$, of which 1.3 million tons is coal, 1.3 million tons - rock). After the technological cycle of coal beneficiation in Pavlohradska CPP to an indicator of $25 \%$ (according to the TPP requirements), the separated $25 \%$ of rocks are supplied to waste dumps and tailing dumps on the surface. Also, based on the maximum annual capacity of all mines, it should be noted that the volume of underground mine workings and the outcrop of these rocks to the mine surface will also be the maximum due to the need to prepare a significant part of the reserves for extraction. 
3.2. Analysis of mining-geological and miningengineering parameters of the mine development with a high volume of waste rock outcrop

The highest volume of rock outcrop is observed during operation of the Heroiv Cosmosu mine, which is located in the Pavlohradsko-Petropavlivskyi coal-mining region of the Western Donbass. Administratively, the mine is located on the territory of the Pavlohrad region, the village of Verbky, $15 \mathrm{~km}$ north-east of Pavlohrad city, Dnipropetrovsk oblast (Fig. 4).

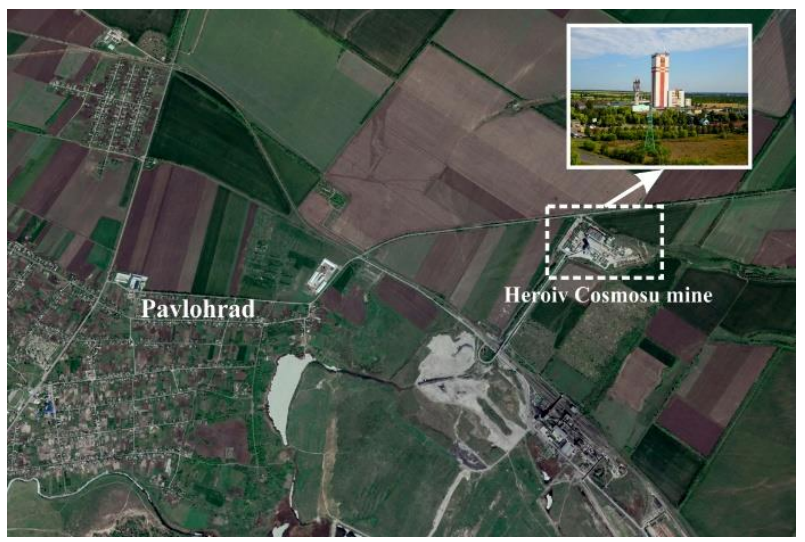

Figure 4. Heroiv Cosmosu mine location

Commercial reserves of the Heroiv Cosmosu mine field account for $68 \%$, and non-commercial reserves $-32 \%$ of total reserves. The mine has 14 coal seams on its balance sheet. Coal reserves in seams less than $0.80 \mathrm{~m}$ thick are almost 190 million tons, of which in seams: $0.50-0.59 \mathrm{~m}-5.1 \%$; $0.60-0.80 \mathrm{~m}-$ $39.8 \%$ (Fig. 5). Seven coal seams, namely $\mathrm{C}_{11}, \mathrm{C}_{10}{ }^{\mathrm{t}}, \mathrm{C}_{9}, \mathrm{C}_{8}^{\mathrm{b}}$, $\mathrm{C}_{7}^{\mathrm{b}}, \mathrm{C}_{5}, \mathrm{C}_{1}$ are of commercial significance. Mining operations in the mine are conducted across the seams $\mathrm{C}_{11}, \mathrm{C}_{10}{ }^{\mathrm{t}}$ and $\mathrm{C}_{9}$.
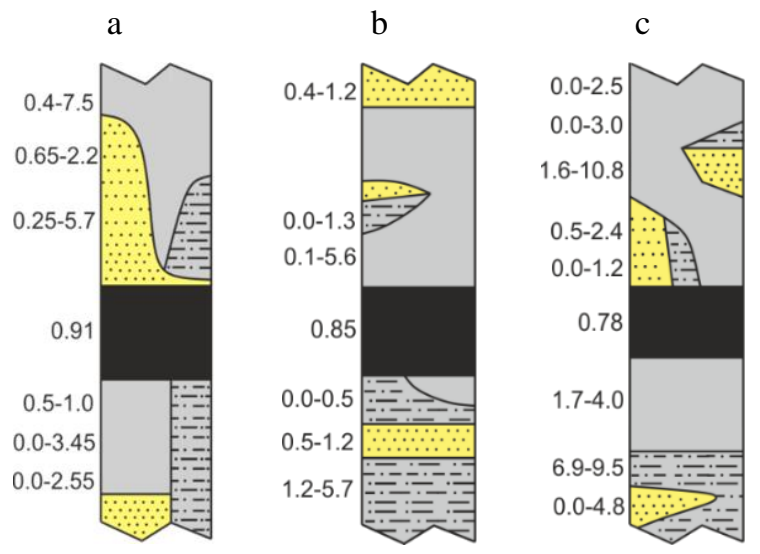

Figure 5. Structural columns of coal seams development in the Heroiv Cosmosu mine: (a) seam $C_{11}$; (b) seam $C_{10}{ }^{t}$; (c) seam $C_{9}$

The main roof is represented by interlaying of argillite, siltstones and sandstones with the same physical and mechanical characteristics as the immediate roof. The false roof, when mining the seam, extends over the entire area with a thickness of up to $0.15 \mathrm{~m}$. The seam bottom is represented by argillite, up to $0.5-2.0 \mathrm{~m}$ thick, with a compressive resistance of up to $10 \mathrm{MPa}$. Siltstones and sandstones occur below the argillite. The compressive resistance $\sigma_{\text {compr }}$ of argillite averages $18 \mathrm{MPa}$, siltstones $\sigma_{\text {compr }}-18.5 \mathrm{MPa}$, and sandstone $\sigma_{\text {compr }}-32 \mathrm{MPa}$.
Scheme of a mine field exposure. The mine field is exposed through two centrally doubled vertical shafts. Ventilation scheme is central. A method of ventilation is suction. The length of the longwall face is $220-250 \mathrm{~m}$. The preparation of the mine field is horizon-oriented. The seams $\mathrm{C}_{10}{ }^{\mathrm{t}}$ and $\mathrm{C}_{11}$ are prepared using the grouping main mine workings, a similar one is designed for seams $\mathrm{C}_{9}$ and $\mathrm{C}_{8} \mathrm{~b}$. Extraction panels are mined in a staggered ordering through the pillar and with extraction drifts driven by undercutting, as well as sequential or repeated use of mine workings. The extraction panel length reaches 800$1600 \mathrm{~m}$, parameters of stope operations are given in Table 1.

Table 1. Parameters of stope operations on the seams

\begin{tabular}{lccc}
\hline Seam & $\begin{array}{c}\text { Geological thickness } \\
\text { Extracting thickness }\end{array}$ & $\begin{array}{c}\text { Mining } \\
\text { equipment }\end{array}$ & $\begin{array}{c}\text { Daily rate of } \\
\text { mining, t/day }\end{array}$ \\
\hline $\mathrm{C}_{11}$ & $\frac{0.72-0.93}{1.05}$ & $\begin{array}{c}\text { support KD-90, } \\
\text { shearer KA-200, } \\
\text { conveyor SP-251 }\end{array}$ & \multirow{2}{2}{$2000-2500$} \\
\cline { 1 - 2 } $\mathrm{C}_{10}{ }^{\mathrm{t}}$ & $\frac{0.83-1.10}{1.05}$ & $\begin{array}{c}\text { support KD-99, } \\
\text { shearer KA-200, } \\
\text { conveyor SP-251 }\end{array}$ & \\
\cline { 1 - 2 } $\mathrm{C}_{9}$ & $\frac{0.85-1.10}{1.05}$ & &
\end{tabular}

Tunnelling machines of the 1GPKS type, such as KSP-32, KSP-35 and EBZ-16, are used for driving the main and extraction mine workings. In the mine, to ensure the main cargo flow, a complete conveyerisation system with belt conveyers of 2LT-80, 1LT-80, 1L-80, 2LTP-1000KSP, 1L-100K, 2LB-120, 2LT1000U, 1L1000-01 type is used, starting from the stope faces to the loading device of the main shaft. Main and extraction mine workings are fastened by frame and frame-roof-bolting support.

The conditions of the mine field exploitation are complex, a complicating factor is the occurrence of soft rocks, which sharply lose their strength when are watered. The seams $\mathrm{C}_{9}, \mathrm{C}_{10}{ }^{\mathrm{t}}$ and $\mathrm{C}_{11}$, which are the main commercial ones, are relatively sustained in terms of thickness and area of distribution among the 14 coal seams that are on the mine's balance sheet.

\subsection{Algorithm for analytical studies of rock volumes and mined-out area in mines}

The purpose set has been achieved using analytical tools, based on the actual state and position of mining operations, actual performance indicators, as well as the achieved modern mining-engineering parameters of the coal seams mining in the Heroiv Cosmosu mine. An analytical assessment of the volume of waste rock outcropping and formed underground cavities is given for a calendar year at a stable level of the planned mine production capacity of 2.6 million tons. A detailed analysis of the mine's flowsheet leads to conclusion that the waste rock movement from the mine to its surface occurs as a result of functioning the production processes during underground mining - stope operations, mine workings and mine workings repair.

\subsubsection{Determining the volume of rocks outcrop from stope operations}

To determine the volume of waste rock outcrop in the course of stope operations, the following parameters are analysed: quantity of mined longwall faces (pcs); longwall face length $(\mathrm{m})$; stope face advance (m/year); structural column of the seam and rocks of each longwall face; geological thickness of the seam $(\mathrm{m})$; extracting thickness of the seam 
(m); parent ash content of the seam $(\%)$; thickness of undercut bottom rocks $(\mathrm{m})$; stope face advance $(\mathrm{m} / \mathrm{month})$; coal density with account of the seam ash content $\left(\mathrm{t} / \mathrm{m}^{3}\right)$; density of undercut bottom rocks $\left(\mathrm{t} / \mathrm{m}^{3}\right)$; false roof thickness $(\mathrm{m})$, density of roof rocks caved $\left(\mathrm{t} / \mathrm{m}^{3}\right)$. The actual data of the mine on mining operations and stope faces advance on a monthly basis are used in the research.

The volume of rocks formation, taking into account the specified mining-engineering parameters, is studied in the stope faces on the working seams $C_{9}-913,952,961 ; C_{10}{ }^{t}-$ $1026,1054,1071,1086 ; C_{11}-1160,1158$. The waste rock movement from the stope faces occurs due to the presence of natural parent ash content in the seam, the need to undercut the host rocks, as well as the false roof caving during coal mining. The coal seam of the extraction site contains rock inclusions and waste rock interlayers called parent ash. The computational scheme for determining the volumes of waste rock formation during the stope operations is shown in Figure 6.

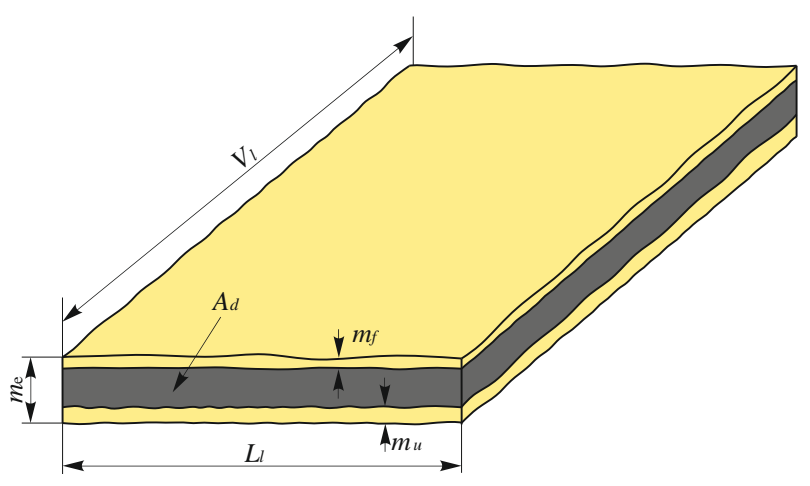

Figure 6. Computational scheme for determining the volume of rocks outcropping from the stope face of the extraction site: $m_{e}$ - extracting seam thickness, $m ; A_{d}$-parent ash content, \%; $m_{f}$-caved rocks layer of the false roof, $m$; $L_{l}$-longwall face length, $m$; $m_{u}$ - thickness of undercut bottom rocks, $m$; $V_{l}$-longwall face advance per year, $m$

The total rock outcrop from the extraction site $Q_{t o t}$ is determined:

$Q_{\text {tot }}=Q_{1}+Q_{2}+Q_{3}, \mathrm{t}$,

where:

$Q_{1}$ - natural rock inclusions in the seam (parent ash content), $\mathrm{t}$;

$Q_{2}$ - caved rocks of the false roof, $\mathrm{t}$;

$Q_{3}$ - rocks of undercutting, $\mathrm{t}$.

The volume of rock outcrop as natural inclusions of the seam $Q_{1}$ is determined:

$Q_{1}=\frac{A_{d} \cdot A_{c . r .}}{100}, \mathrm{t}$,

where:

$A_{d}$ - parent ash content of the coal seam, \%;

$A_{\text {c.r. }}$ - commercial coal reserves of the extraction site, $\mathrm{t}$.

The volume of rock outcrop due to caving of the false roof $Q_{2}$ is determined:

$Q_{2}=m_{f} \cdot L_{l} \cdot V_{l} \cdot \gamma_{f}, \mathrm{t}$,

where:

$m_{f}-$ thickness of the caved rock layer after the shearer operating member passage, $\mathrm{m}$;
$L_{l}$ - longwall face length, $\mathrm{m}$;

$V_{l}$ - longwall face advance per year, $\mathrm{m}$;

$\gamma_{f}$ - false roof rocks density, $\mathrm{t} / \mathrm{m}^{3}$.

The volume of rocks from the bottom rocks $Q_{3}$ undercutting is determined:

$Q_{3}=m_{u} \cdot L_{l} \cdot V_{l} \cdot \gamma_{u n}, \mathrm{t}$,

where:

$m_{u}$ - thickness of undercut bottom rocks, $\mathrm{m}$;

$L_{l}$ - longwall face length, $\mathrm{m}$;

$V_{l}$ - longwall face advance per year, $\mathrm{m}$;

$\gamma_{u n}-$ undercut rocks density, $\mathrm{t} / \mathrm{m}^{3}$.

Taking into account all the sources of rock formation from the stope faces, it is possible to quite objectively assess the ash content, close to the actual one, and, accordingly, the formation of waste rock flow onto the surface, with a high probability corresponding to the fact.

\subsubsection{Determining the volume of rocks outcrop from mine workings}

To determine the waste rock outcrop during the process of mining operations, the following parameters are analysed: excavated cross-sectional area of a mine working $\left(\mathrm{m}^{2}\right)$; coal face area $\left(\mathrm{m}^{2}\right)$; density of roof and bottom rocks $\left(\mathrm{t} / \mathrm{m}^{3}\right)$; mine working length $(\mathrm{m})$.

The volume of rocks formed, taking into account the specified mining-engineering parameters, is studied in drifting faces across the working seams $\mathrm{C}_{9}$ : $911,917,954,961$, 967 haulage and ventilation drifts and 919 ventilation drift; $\mathrm{C}_{10}{ }^{\mathrm{t}}-1026$ haulage and ventilation drifts, 1086; $\mathrm{C}_{11}-1160$ haulage drift and by-pass. The waste rocks movement from the drifting faces occurs mainly due to the total extraction of the coal seam and rocks by the operating member of the tunnelling machine. Broken rock with coal from the drifting face is delivered to the surface in a single traffic flow and is stockpiled in a rock dump. In the course of work, only the rock flow from the drifting face is determined, since coal is a valuable component in the dump and can be recovered in the near future [44]. The computational scheme for determining the volumes of waste rock formed during the mine working is shown in Figure 7.

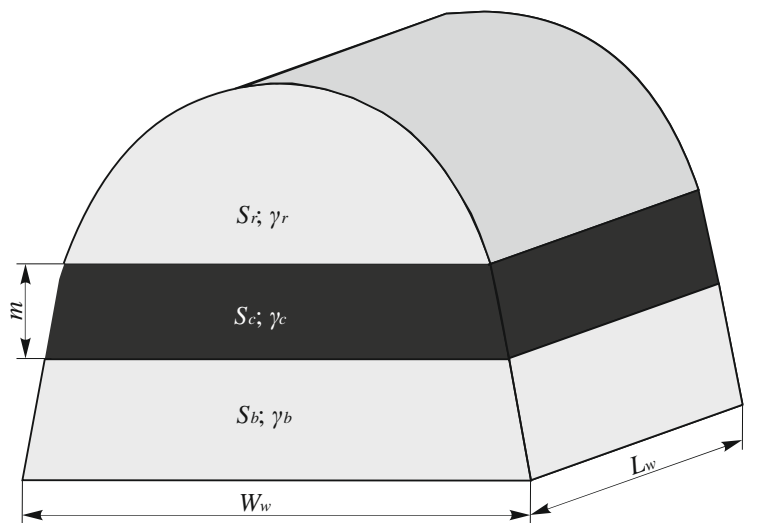

Figure 7. Computational scheme for determining the volume of rocks outcrop from the drifting face: $S_{r}$ - rock face area of roof, $\mathrm{m}^{2} ; \gamma_{r}$-density of rocks of roof, $t / \mathrm{m}^{3} ; S_{c}-$ coal face area, $\mathrm{m}^{2} ; \gamma_{c}$-density of coal seam, $t / \mathrm{m}^{3} ; S_{b}$-rock face area of bottom, $m^{2} ; \gamma_{b}$-density of rocks of bottom, $t / m^{3} ; m$ - coal seam thickness, $m ; W_{w}$-excavated mine working width, $m ; L_{w}$-length of mine working with rocks heaving, $m$ 
The volume of rocks outcrop from mine workings conducted across the seam, is determined:

$Q_{w . s .}=\left(S_{w}-S_{c}\right) \cdot L \cdot \gamma, \mathrm{t}$,

where:

$S_{w}$ - excavated cross-sectional area of mine working, $\mathrm{m}^{2}$;

$S_{c}$ - coal face area of mine working, $\mathrm{m}^{2}$;

$S_{w}-S_{c}=S_{\text {rock }}$ - rock face area of mine working, $\mathrm{m}^{2}$;

$L$ - longwall face advance per year, $\mathrm{m}$;

$\gamma$-density of roof and bottom rocks of mine working, $t / \mathrm{m}^{3}$.

The volume of rocks outcrop from mine workings conducted on the waste rocks is determined:

$$
Q_{w . s .}=S_{m . w .} \cdot L \cdot \gamma, \mathrm{t}
$$

Taking into account all the mine workings conducted during the calendar year according to the mining plan, it is possible to most accurately determine the volume of rocks outcrop from the drifting.

\subsubsection{Determining the volume of rocks outcrop in case of ripping the bottom of mine workings}

As a consequence of the intense rock pressure manifestation caused by the great mining depth $(300-600 \mathrm{~m})$ and the occurrence of soft host rocks of argillite and siltstones, capable of losing strength when exposed to water, the bottom rocks of mine workings can heave. With the value of bottom heaving in the mine working of $0.5 \mathrm{~m}$, there is a technological need for ripping the heaven bottom, which is also supplied to the dump on the surface. The rocks heaving is especially active in the mine workings used repeatedly, intensifying ahead and behind the stope face. In the extraction mine workings, which are abandoned behind the longwall face, the intensity of bottom heaving is less, and there is no need in ripping the bottom. The greatest rock pressure manifestations in the Western Donbass are observed in the Zakhidno-Donbaska mine, Stepova mine, Heroiv Cosmosu mine. The value of heaving in the extraction mine workings is within 1.0-1.5 m.

The research is focused on the heaving of bottom in the extraction mine workings only, since $80 \%$ of the repair work accounts for bottom ripping of the extraction mine workings, which are used repeatedly [45], [46]. The stability of the main in-seam workings is much higher. Based on the analysis of the mining plan for studied calendar year, the extraction drifts were repeatedly used only in the 1054 and 1160 longwall faces, in the rest they are abandoned.

The volume of rocks outcrop after ripping the bottom of mine workings over its entire width is determined:

$Q_{w . s .}=W_{w} \cdot h_{n} \cdot L_{w} \cdot \gamma_{b}, \mathrm{t}$,

where:

$W_{w}$ - excavated mine working width, $\mathrm{m}^{2}$;

$h_{n}$ - height of bottom rocks ripping, $\mathrm{m}$;

$L_{w}$-length of mine working with rocks heaving, m;

$\gamma_{b}-$ density of bottom rocks of mine working, $\mathrm{t} / \mathrm{m}^{3}$.

When expressing analytically, it is possible to quite accurately determine the volume of rock outcrop after ripping the bottom. It should be noted that, in comparison with the rock outcrop in the process of stope and drifting operations, the volume of rock outcrop after ripping is an order of magnitude lower.

\subsubsection{Determination of prospective underground cavities volumes for the possibility of placing the waste rocks}

To plan the maximum capability of stockpiling the rock in the mined-out area of a mine through its filling or placing, it is necessary to know about potentially promising volumes of formed underground cavities. A peculiarity is that the volumes of cavities are constantly changing in time and space with the development of mining operations in the mine field. Therefore, to achieve a complete balance "formation disposal of rocks", it is necessary to foresee certain spatial planning transformations when preparing the mine field. However, first of all, a practical task should be set - to find out the physical ability of the maximum possible placement of the formed waste rocks in the formed underground cavities of the mine per a calendar year.

The volume of the formed mined-out area $Q_{n 1}$ during the stope operations is determined:

$Q_{n 1}=\left(m_{e}+m_{f}\right) \cdot L_{l} \cdot V_{n}, \mathrm{~m}^{3}$,

where:

$m_{e}-$ extracting seam thickness, $\mathrm{m}$;

$m_{f}-$ caved rocks layer of the false roof, $\mathrm{m}$;

$L_{l}$ - longwall face length, $\mathrm{m}$;

$V_{n}$ - longwall face advance per year, $\mathrm{m}$.

There are technologies for mining the seams with backfilling and new ones are being developed that allow to form a rock pack under the protection of the reverse cantilever to the width of the shearer gripping, that is, to the full thickness of the seam, without the immediate roof rocks subsidence and reducing the volume of cavities for backfilling.

A promising direction for the possibility of waste rock accumulation is its placement in the cavities of abandoned mine workings, especially the extracted mine workings, following the longwall face advance. A peculiarity is that behind the longwall face, a section of the mine working decreases due to the destroyed rocks pressure in the massif behind the longwall face. It has been determined that behind the longwall face in the conditions of the Western Donbass mines [47], [48], the cross-sectional area of mine working decreases to $60-70 \%$ of the initial design state, which should be taken into account when placing the rocks in these abandoned mine workings.

The volume of cavities of the abandoned mine working behind the longwall face $Q_{n 2}$, when conducting mine workings, is determined:

$Q_{n 2}=0.7 \cdot S_{w} \cdot L_{w}, \mathrm{~m}^{3}$,

where:

$S_{w}$ - excavated cross-sectional area of mine working, $\mathrm{m}^{2}$;

$L_{w}$ - mine working length, $\mathrm{m}$.

To determine the preliminary possibility of placing the formed waste rocks in the formed underground cavities of the mine, it is necessary to take into account the coefficient of loosening the rocks broken by shearers and tunnelling machines, which require a larger volume of cavities. For shearer-loaders, the coefficient of loosening is taken as 1.2-1.3, for tunnelling machines 1.4-1.6 [49]. To determine more accurately, it is necessary to perform a series of experimental studies of the particle-size distribution of the broken rocks by specific models of shearers and tunnelling machines. 


\section{Research results and discussion}

\subsection{Assessing the volumes of waste rock flows movement and identifying the sources of their formation}

During the analysed calendar year of the mine operation along three working seams $\mathrm{C}_{9}, \mathrm{C}_{10}{ }^{t}, \mathrm{C}_{11}$, stope operations were conducted in 9 stope faces -5 extraction panels were fully mined-out, and 4 - incompletely mined-out, which is explained by the calendar year changeover. The mine production capacity amounted to 2.55 million tons of rock mass, of which 2.25 million tons were mined from the stope faces, and almost 300 thousand tons from the drifting faces. A peculiarity of the mine is that the rock mass from the stope faces and the faces of preparatory mine workings is transported by sectional conveyors to one main conveyor. Here it is mixed and moves through the complete conveying system to the mine shafts, and from the drifting faces of the mine openings - separately, by locomotive transport. The rock mass from the drifting faces significantly increases the ash content of the mined rock mass (from 37 to $42.5 \%$ ), which in the perspective requires the separation of traffic flows. Nevertheless, in further research, the waste rock flows are differ- entiated in terms of different specifications of the stope and drifting operations.

Shearer-loaders KA-200 in the faces perform the bulk mining along the entire extracting thickness of the coal seam of $1.05 \mathrm{~m}$. In the studied stope faces, undercutting of bottom rocks by a shearer-loader to a value of up to $0.33 \mathrm{~m}$ was noted, as well as constant caving of the false roof rocks of the seam (soft argillite) into broken coal with a thickness of $0.06-0.09 \mathrm{~m}$. The most important sources are studied of waste rock supply from stope faces as part of the transported mined rock mass, namely, the rocks of seam ash content, caved rocks of the false roof and bottom rocks of the seam, undercut by a shearer. Table 2 presents the results of detailed analytical studies on identifying the volumes of waste rocks and the sources of their formation in the composition of the mined rock mass per a calendar year in the Heroiv Cosmosu mine. It should be noted the high convergence of the ash content value of the rock mass from the stope faces when comparing the actual data of the mine $(36.5 \%)$ with analytical calculations $(37.7 \%)$, which indicates an adequate task setting and methodological apparatus used.

Table 2. Research results of waste rock formed as a result of stope operations conducted for a calendar year

\begin{tabular}{|c|c|c|c|c|c|c|c|c|c|c|c|c|c|c|c|c|}
\hline Seam & $\begin{array}{l}\text { Long } \\
\text { wall } \\
\text { face }\end{array}$ & $m_{e}, \mathrm{~m}$ & $\begin{array}{c}m_{\text {geol }}, \\
\mathrm{m}\end{array}$ & $A_{d}, \%$ & $L_{l}, \mathrm{~m}$ & $V_{n}, \mathrm{~m}$ & $m_{f}, \mathrm{~m}$ & $m_{u}, \mathrm{~m}$ & $\begin{array}{l}\gamma_{\text {coal }}, \\
\mathrm{t} / \mathrm{m}^{3}\end{array}$ & $\begin{array}{c}\gamma_{f}, \\
\mathrm{t} / \mathrm{m}^{3}\end{array}$ & $\begin{array}{l}\gamma_{u n}, \\
\mathrm{t} / \mathrm{m}^{3}\end{array}$ & $\begin{array}{l}A_{c . r .}, \\
\text { ths. } \\
\text { tons }\end{array}$ & $\begin{array}{c}\text { Ar.m., } \\
\text { ths. } \\
\text { tons }\end{array}$ & $\begin{array}{l}Q_{1}, \\
\text { ths. } \\
\text { tons }\end{array}$ & $\begin{array}{c}Q_{2} \\
\text { ths. } \\
\text { tons }\end{array}$ & $\begin{array}{l}Q_{3}, \\
\text { ths. } \\
\text { tons }\end{array}$ \\
\hline \multirow{3}{*}{$\mathrm{C}_{9}$} & 913 & \multirow{9}{*}{1.05} & 0.78 & \multirow{3}{*}{9.0} & 270 & 561 & 0.06 & 0.27 & 1.27 & 2.31 & 2.36 & 150.4 & 274.2 & 13.5 & 20.99 & 96.5 \\
\hline & 952 & & 1.0 & & 196 & 840 & 0.07 & 0.05 & 1.27 & 2.33 & 2.37 & 209.1 & 246.6 & 18.8 & 26.85 & 19.5 \\
\hline & 961 & & 0.91 & & 250 & 651 & 0.07 & 0.1 & 1.27 & 2.35 & 2.37 & 188.1 & 276 & 16.9 & 26.77 & 38.6 \\
\hline \multirow{4}{*}{$\mathrm{C}_{10}{ }^{\mathrm{t}}$} & 1026 & & 0.89 & \multirow{4}{*}{8.0} & 250 & 499 & 0.06 & 0.16 & 1.25 & 2.33 & 2.35 & 138.1 & 210.8 & 111.0 & 17.44 & 46.9 \\
\hline & 1054 & & 0.90 & & 250 & 929 & 0.07 & 0.15 & 1.25 & 2.38 & 2.34 & 261.3 & 390.5 & 20.9 & 38.7 & 81.5 \\
\hline & 1071 & & 0.87 & & 270 & 59 & 0.09 & 0.18 & 1.25 & 2.35 & 2.34 & 173.2 & 26.4 & 1.4 & 3.36 & 6.7 \\
\hline & 1085 & & 0.92 & & 250 & 1346 & 0.07 & 0.13 & 1.24 & 2.35 & 2.35 & 383.9 & 544.5 & 30.7 & 55.35 & 102.8 \\
\hline \multirow{2}{*}{$\mathrm{C}_{11}$} & 1158 & & 0.72 & \multirow{2}{*}{13.0} & 250 & 147 & 0.06 & 0.33 & 1.29 & 2.32 & 2.38 & 34.1 & 69.0 & 4.1 & 5.1 & 28.9 \\
\hline & 1160 & & 0.72 & & 250 & 447 & 0.06 & 0.33 & 1.29 & 2.33 & 2.38 & 103.8 & 211.8 & 12.4 & 15.6 & 87.7 \\
\hline \multicolumn{14}{|c|}{ Rock outcrop volume by category } & 129.9 & 210.1 & 509.1 \\
\hline \multicolumn{14}{|c|}{ Total rock outcrop volume } & & 849.1 & \\
\hline
\end{tabular}

${ }^{*} Q_{1}$ - rock outcrop volume from parent ash content of the seam, thousand tons; $Q_{2}$ - rock outcrop volume from caving, thousand tons; $Q_{3}$ - rock outcrop volume from undercutting, thousand tons

A comprehensive study of the most important technical and geometrical stope faces parameters for a calendar year, their advance velocities, physical-chemical characteristics of rocks and the seam make it possible to determine the amount of waste rocks formed during stope operations -850 thousand tons, which is $37.7 \%$ of mined coal ash content. Waste rocks in the composition of mined coal perform an indicator of operational ash content and, with its high values, predetermine the need to use technological processes of beneficiation, which affects the cost of coal mining. Based on the Table 2 data analysis, it is possible to conclude that the largest waste rock volume in the process of conducting the stope operations accounts for the forced undercutting of bottom rocks by a shearer-loader $(60 \%)$. It has also been revealed that $24.7 \%$ accounts for the false roof caving after the passage of the shearer operating member along the entire length of the stope face and $15.3 \%$ is the natural ash content of the coal seam. The structure of rock outcrop from the stope faces is shown in Figure 8.

It should be noted that the rock outcrop structure is significantly influenced by the geological thickness of the seam, as well as the host rock structure of the roof and bottom.

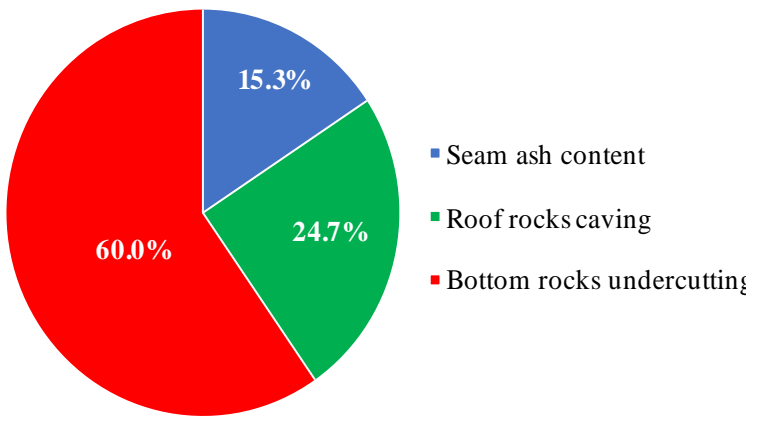

Figure 8. Structure of the waste rock outcrop distribution when conducting the stope operations

Thus, with an increase in the coal seam geological thickness and the absence of a false roof, the mined coal ash content will be an order of magnitude lower. Therefore, the research results are valid only for the mine field of the studied mine, which contains the seams $\mathrm{C}_{9}, \mathrm{C}_{10}{ }^{\mathrm{t}}, \mathrm{C}_{11}$.

There are various methods to reduce the waste rock movement in the mined rock mass. It is possible to reduce the mined coal ash content by creating underground coal beneficiation 
systems with leaving or backfilling the rocks in the mined-out area. Also, a promising method is chemical strengthening or undercutting by a shearer-loader of the seam roof rocks (instead of bottom rocks) with the extraction of the false roof, followed by a more stable roof - immediate. However, it is possible to fundamentally reduce the waste rocks proportion in the rock mass by using new options for selective mining technology with backfilling of the mined-out area [50], [51]. This will make it possible to extract coal with an ash content sufficient for the technological requirements of TPPs.

The basis for performing the stope operations is the timely preparation of new coal reserves by creating a front for drifting operations for mine openings and preparatory mine workings, as a result of which there is a constant formation of waste rocks. So, for the studied calendar year, $17000 \mathrm{~m}$ of mine workings were driven, of which $13300 \mathrm{~m}$ were preparatory mine workings, $3700 \mathrm{~m}$ - mine openings. The parameters of all mine workings of the mine have been studied, taken into account that the mine working was conducted across the seam or waste rocks with the introduction of the hard heading coefficient. Table 3 presents the results of detailed analytical studies to identify the waste rock volumes and the sources of their formation as a result of drifting operations across the seams. The largest volume of preparatory mine workings was conducted along the $\mathrm{C}_{9}$ seam, where it is also noted its higher share in the coal output distribution in the mine.

According to Table 3, it has been determined that about 430 thousand tons of waste rock, formed in the drifting faces, is supplied to the surface through the mine transport systems. The waste rock from drifting operations moves as follows. From the faces of the preparatory mine workings, a mixture of waste rock with coal (70/30) is transported by a sectional conveyor to the main conveyor, where the rocks after drifting are mixed with the mined rock mass and delivered to the shafts. When lifted by coal skips, the mined rock mass with an ash content of $42.5 \%$ is transported to the processing plant, where waste rock is separated: large fractions return to the waste dump, small fractions - to the tailing dump. From the faces of mine openings, clean waste rock in trolleys is delivered by locomotives to the shafts into rock skips, after unloading to the surface, they are transported directly to the rock dump. The structure of rock outcrop from drifting faces is shown in Figure 9.

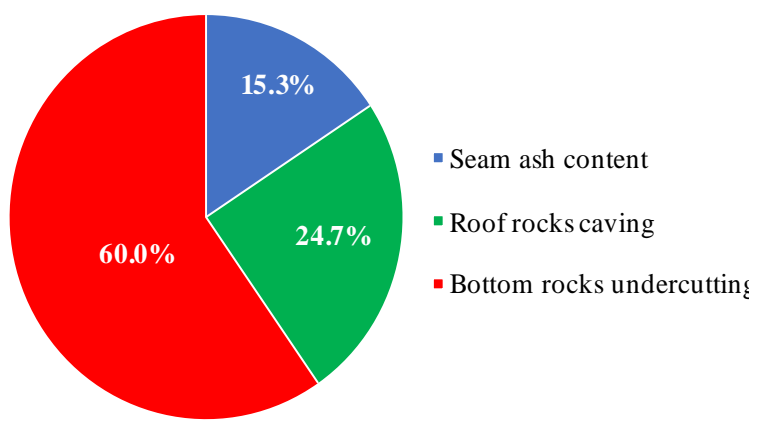

Figure 9. Structure of the waste rock outcrop distribution when conducting the drifting operations

It follows from Figure 9 that when conducting mine workings, the volume of waste rock outcrop is represented by $63 \%$ from the faces of the preparatory extraction workings, and $37 \%$ - from the faces of the mine openings (crosscuts, slopes, main drifts).
Table 3. Research results of waste rock formed from drifting operations per a calendar year

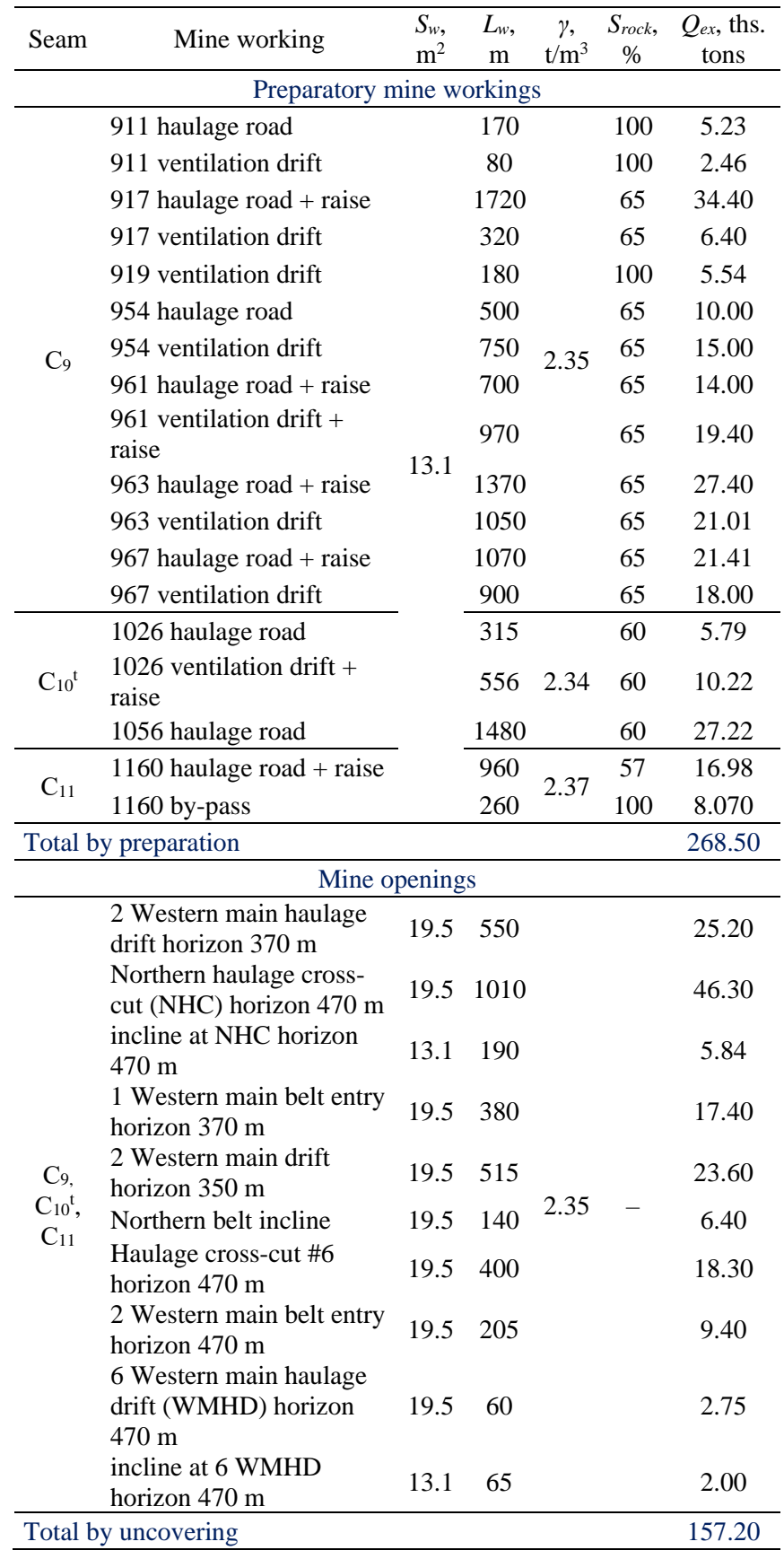

It should be noted that in modern coal mines, where there are 4 stope faces in simultaneous operation, at least 8 drifting faces of preparatory mine workings should function in order to timely prepare a new front of stope operations (with repeated use $-4 \mathrm{pcs}$ ). Thus, if there are 2-3 stope faces, then the required number of drifting faces also decreases proportionally, hence, the volume of rock outcrop from the preparatory faces decreases and the structure shown in Figure 9 may change significantly.

The production process, resulting in an additional volume of rock outcrop, is the repair of mine workings, namely, the bottom rocks ripping. The bottom rocks ripping is conducted mainly in repeatedly used extraction mine workings, which are exploited when mining two longwall faces. If the extraction mine workings are abandoned immediately after the longwall face advance, then in this case heaving ahead of the longwall face does not exceed the critical value due to its rapid mining 
(the panel length is $800-1000 \mathrm{~m}$ ). Thus, during the studied calendar year, the bottom ripping with a length of $1360 \mathrm{~m}$ was performed in 1054 and 1160 haulage roads to a height of $1.0 \mathrm{~m}$, along the width $4.3 \mathrm{~m}$ of mine workings, and also partially in other main mine workings. The volume of waste rocks outcrop from bottom ripping amounted to 25.0 thousand tons.

A comprehensive analysis of the waste rock flows movement in the coal mine technological system made it possible to identify the sources of their formation and quantify their influence on the waste rock accumulation on the surface, which is represented in Figure 10.

Analysis of Figure 10 provides an important concept of the isolated movement of waste rock flows in the Heroiv Cosmosu mine. It has been determined that the greatest sup- ply of all waste rocks to the surface occurs due to the stope operations with the bottom rocks undercutting - 39\% and underground mine workings to prepare new coal reserves for extraction $-33 \%$, other sources in comparison have a small specific weight within the range of $2-6 \%$. This evidences that in order to solve the problem of achieving low-waste in coal mining technology, it is first of all necessary to improve and modernize the flowsheets of stope and drifting operations with the waste rock placement in underground cavities. To assess the possibility of reducing the volume of rock outcropping to the surface, the waste rock flows should be considered in detail separately, since, it is possible, using a number of technical solutions, to influence directly in underground conditions on their amount.

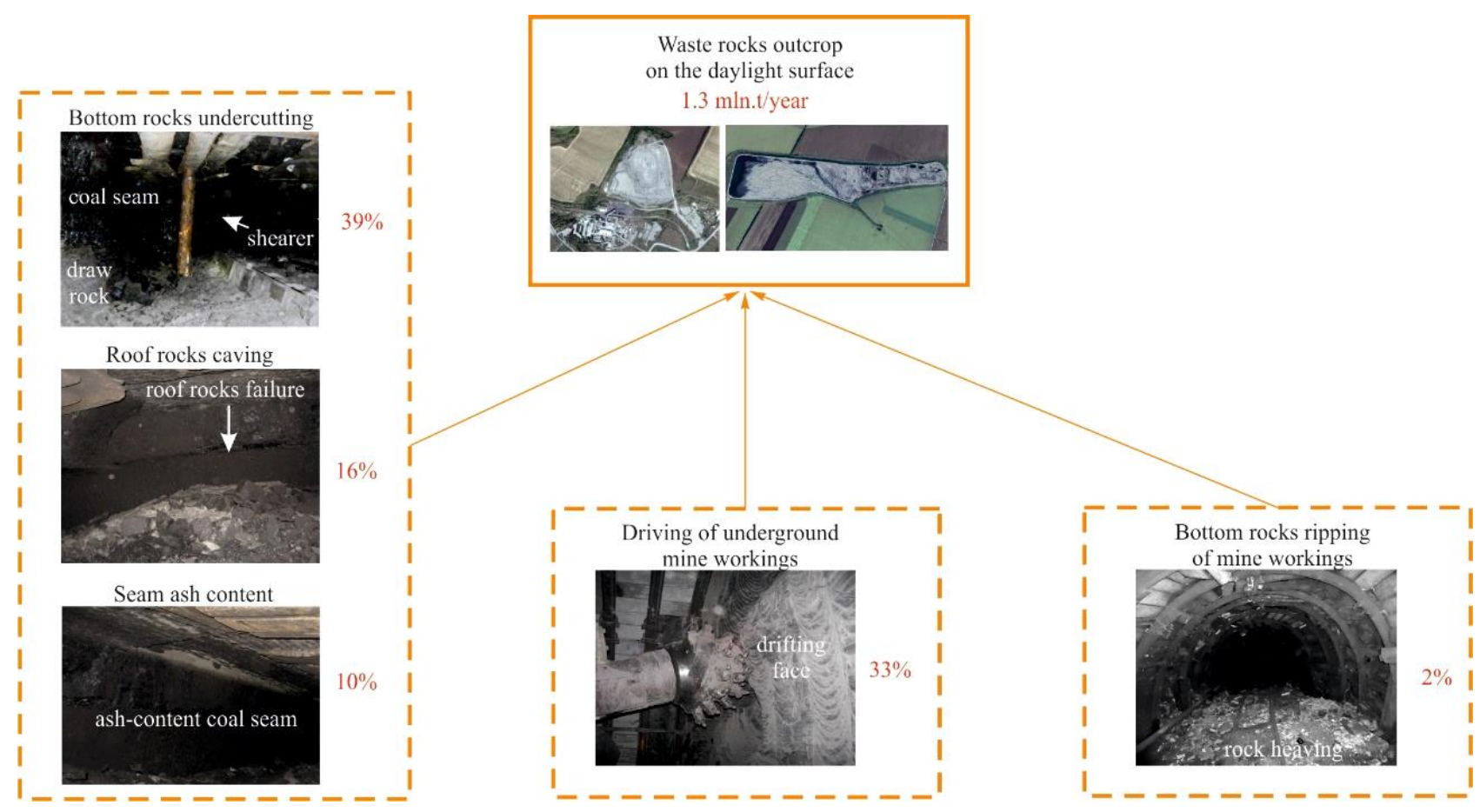

Figure 10. Sources of waste rock supply to the surface from the mine flowsheet

By the nature and complexity of implementing the potential technical solutions, which are related to the rocks placement in the underground space, the entire volume of waste rock outcrop from the mine can be differentiated into 2 categories:

- rocks which are difficult to dispose of - they also include waste rocks from the roof rocks caving and seam ash content rocks. Their placement in the underground cavities leads to technological difficulties and economic expenditures associated with the designing and construction of underground coal processing complexes, as well as technologies for chemical roof management. This also will not fundamentally solve the problem of leaving the rock in the mine, since their volume does not exceed $26 \%$ of the total amount of waste rocks supplied to the surface. It is also technologically easier to leave the waste rocks in the face immediately after their extraction than to return it to the mined-out area of the longwall face after underground beneficiation;

- rocks prospective for disposal - they include undercut rocks in the stope faces, rocks after bottom ripping in mine workings, the proportion of which in the total rock flow is $74 \%$. They are proposed to be considered as prospective for disposal. In addition, their disposal has economic and ecological significance.

\subsection{Assessing the volumes of the formed underground cavities prospective for the rocks placement}

Technological solutions for the disposal of waste rock of undercutting should be based on the selective breaking-out by a shearer. When supplying from the longwall face through special simplified equipment, the waste rock should be used for backfilling the cavities of the mined-out area behind the longwall face. Disposal of the rocks from mine workings should involve technological solutions for the rational movement of these rocks and their placement in the cavities of the nearest extraction mine workings behind the longwall face, which, according to the mining plan, should be decommissioned. These solutions should largely be based on the improvement of the coal reserves preparation scheme and the new location of mine workings in the area. The rocks after the bottom rocks ripping, mainly from extraction mine workings, with the help of new devices can be directed and added to the rocks of the rock flow from the longwall face, which are used for backfilling of its mined-out space. To develop these technologies, it is necessary to know the balance of the formed underground cavities in the mine to assess the possibility of maximum complete placement of waste rocks in them. 
Based on the results of analytical studies according to the methodology, the potential volumes of mined-out space have been determined, in which it is theoretically possible to place waste rock (Table 4). Underground cavities were formed after stope operations in 8 longwall faces with the simultaneous formation of mined-out space and 16 extraction mine workings, which were abandoned following the longwall face advance. As can be seen from Table 4, the volume of cavities in the mined-out space of longwall faces is by 19 times higher than the volume of cavities of abandoned mine workings.

Table 4. Research results of the underground cavities formed after mining operations

\begin{tabular}{|c|c|c|c|}
\hline Seam & $\begin{array}{c}\text { Type } \\
\text { of cavities }\end{array}$ & $\begin{array}{l}\text { Object } \\
\text { of formation }\end{array}$ & $\begin{array}{c}\text { Volume } \\
\text { of cavities, } \\
\text { ths. } \mathrm{m}^{3}\end{array}$ \\
\hline \multirow{3}{*}{$\mathrm{C}_{9}$} & $\begin{array}{l}\text { mined-out space } \\
\text { of longwall faces }\end{array}$ & $\begin{array}{c}613,952,961 \\
\text { longwall faces }\end{array}$ & 536.4 \\
\hline & abandoned mine & $913,952,961$ & \multirow[b]{2}{*}{33.6} \\
\hline & $\begin{array}{l}\text { workings behind } \\
\text { the longwall face }\end{array}$ & $\begin{array}{c}\text { haulage roads and } \\
\text { ventilation drifts }\end{array}$ & \\
\hline \multirow[b]{2}{*}{$\mathrm{C}_{10}{ }^{\mathrm{t}}$} & $\begin{array}{l}\text { mined-out space } \\
\text { of longwall faces }\end{array}$ & $\begin{array}{l}1026,1054,1071 \\
1085 \text { longwall faces }\end{array}$ & 796.0 \\
\hline & $\begin{array}{l}\text { abandoned mine } \\
\text { workings behind } \\
\text { the longwall face }\end{array}$ & $\begin{array}{c}1026,1071,1085 \\
\text { haulage roads and } \\
\text { ventilation drifts; } \\
1054 \text { ventilation drift }\end{array}$ & 38.8 \\
\hline \multirow[b]{2}{*}{$\mathrm{C}_{11}$} & $\begin{array}{l}\text { mined-out space } \\
\text { of longwall faces }\end{array}$ & $\begin{array}{c}1158,1160 \\
\text { longwall face }\end{array}$ & 165.3 \\
\hline & $\begin{array}{l}\text { abandoned mine } \\
\text { workings behind } \\
\text { the longwall face }\end{array}$ & $\begin{array}{l}1158 \text { haulage road } \\
\text { and ventilation drift; } \\
1160 \text { haulage road }\end{array}$ & 6.0 \\
\hline \multicolumn{3}{|c|}{$\begin{array}{l}\text { Total volume of cavities in the mined-out space } \\
\text { of longwall faces }\end{array}$} & 1497.7 \\
\hline \multicolumn{3}{|c|}{$\begin{array}{l}\text { Total volume of cavities in the abandoned mine } \\
\text { workings behind the longwall face }\end{array}$} & 78.4 \\
\hline \multicolumn{3}{|c|}{ Total mine volume of cavities } & 1576.1 \\
\hline
\end{tabular}

The main peculiarity of the formed underground cavities resulting from mining the coal deposits is their constant dynamic change in space and time. When mining, for example, ore deposits, the cavities formed from the mined stope chambers are static, and the solidifying backfill can be fed into them after 1-1.5 months, therefore, the stope and backfilling operations are separated in time and space [52]-[54].

When mining a coal seam, after a cycle of extraction to the width of gripping by the shearer operating member, the powered roof support sections move to the newly formed face plane, and the rocks of the immediate roof at once collapse into the mined-out space. Thus, the cavities of the mined-out space of the longwall faces are potential for placing the waste rocks. To do this, it is necessary to have time to place the selectively separated rock in the face immediately into the mined-out space of the longwall face before performing a new cycle of seam extraction. The number of extraction cycles per day can reach from 4 to 8 pcs, depending on the length of the longwall face and the equipment used. If the undercut rocks from the stope operations can potentially be immediately backfilled into the mined-out space, then the rocks from the drifting face must be moved to mine working that is to be abandoned behind the longwall face. As for the cavities of the abandoned haulage roads and ventilation drifts behind the longwall face, the mine working is abandoned once a day at a distance equal to the daily longwall face advance. In this case, a new flowsheet for the delivery and placement of waste rocks after mine workings, which can potentially be stockpiled in the abandoned mine workings, should take this aspect into account.

\subsection{Research into balance of formed rocks and underground cavities in relation to mining operations development}

To assess the possibility of placing the waste rocks prospective for disposal (backfilling) into prospective underground cavities, the formed volume of waste rocks is converted from $(\mathrm{t})$ to $\left(\mathrm{m}^{3}\right)$, taking into account the coefficient of loosening. Due to the fact that mining operations in the mine are intensively changing in space and in time, a balance has been drawn up of the simultaneous formation of prospective waste rocks and cavities for each calendar month of the year (Fig. 11).

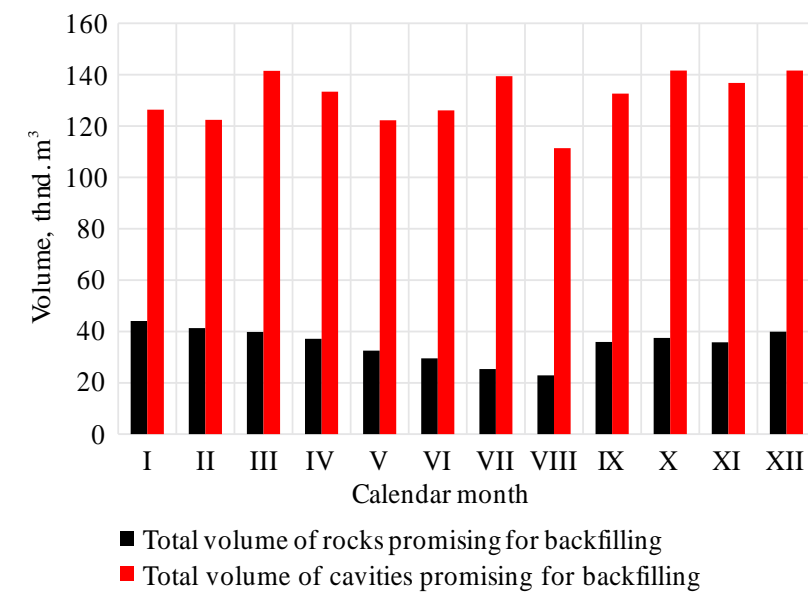

Figure 11. Dynamics of the formed total rock volume and underground cavities, promising for backfilling

From Figure 11 analysis, it can be seen that the volume of waste rocks promising for placing in cavities varied monthly within 22.9-44.1 thousand $\mathrm{m}^{3}$, and prospective underground cavities - within 111.4-141.6 thousand $\mathrm{m}^{3}$. The values variation is primarily caused by commissioning into operation and decommissioning of longwall faces with different parameters, idle time during commissioning of new longwall faces, the difference in the rate of stope and drifting faces advance. It has been determined that underground cavities have a colossal potential for the placement of waste rocks from stope, drifting and repair works, the volume of formation of which is by 2.8-4.8 times higher than the volume of rocks formation. Thus, during each month of the year there will not be a lack of underground cavities, and given the indicators of the "cavities-rock" balance difference, it would be more correct to leave the rocks in the mine instead of backfilling.

Based on the fact that the formed rocks, prospective to be left in the underground space of mines, have varied source of formation (stope and drifting works), and they are supposed to be placed in different types of underground cavities. Consequently, different variants of the balance change dynamics have been drawn up (Fig. 12).

From Figure 12 a analysis, it can be seen that with account of the volume of waste rocks formed from undercutting the bottom rocks, the cavities of the mined-out longwall faces have a significant reserve for their placement. With an averaged value of bottom rocks undercutting of $0.2 \mathrm{~m}$ over 8 mined longwall faces, the volume of their cavities formation exceeds the waste rock outcrop by 3.8-10.0 times. 
(a)

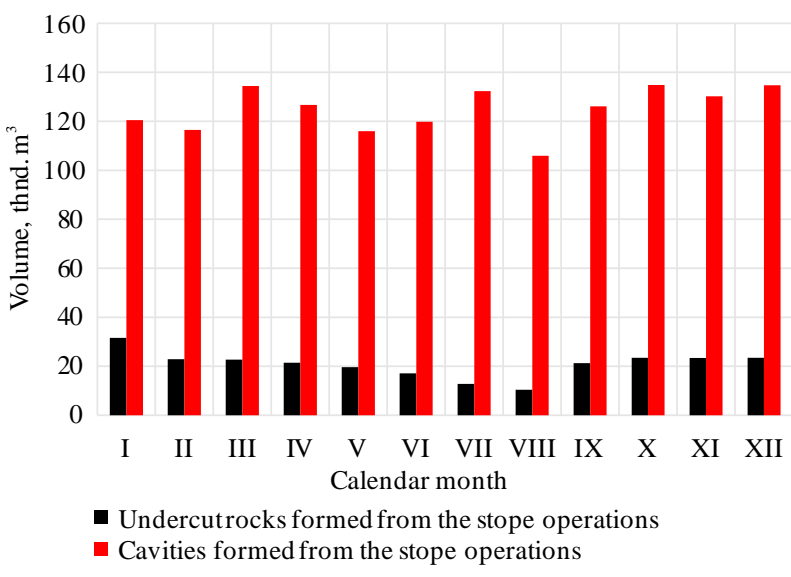

(b)

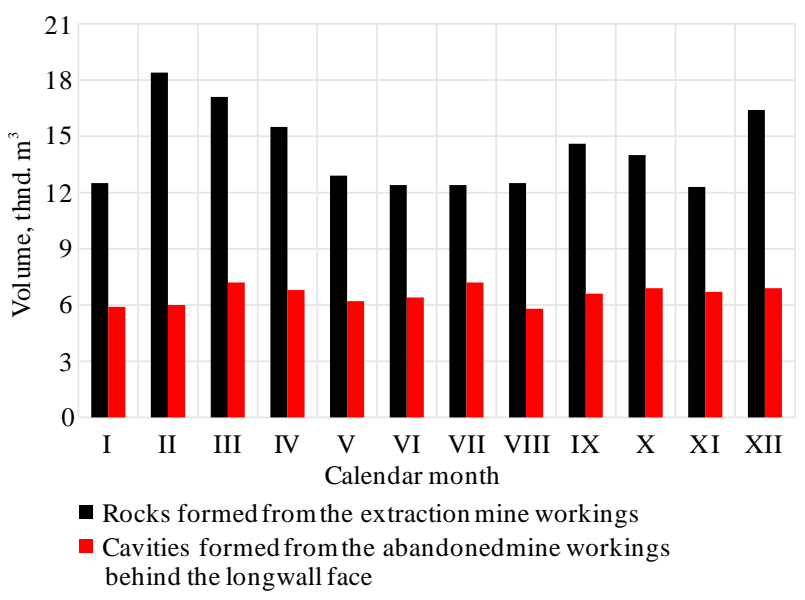

Figure 12. Dynamics of forming the volume of undercut rocks of and cavities of the mined-out longwall faces (a) and the volume of rocks from extraction mine workings and cavities for the existing extraction mine workings (supposed to be abandoned) behind the longwall face (b)

This indicates that with the improvement of the selective technology of mining the reserves with backfilling, it becomes possible to involve into operation the coal seams with a lower geological thickness of 0.5-0.8 m. In this case, even with the value of undercutting of $0.5 \mathrm{~m}$, it is possible to place all the rock in the cavities of the mined-out space.

From Figure $12 \mathrm{~b}$ analysis, it can be seen that the volume of rocks formed when conducting 18 new extraction mine workings per a calendar year is by 2.1-3.0 times higher than the volume of cavities formed when decommissioning 14 extraction mine workings following the longwall face advance. The noted imbalance is caused by the significant influence of the coefficient of rocks loosening $\left(k_{l}=1.5\right)$ on the increase in their volume in the destroyed state after the destruction of the face by the tunnelling machine. From this it follows that the cavities of the abandoned extraction mine workings do not allow to place the entire volume of waste rock outcrop from the drifting faces, which requires new technical solutions. To solve this issue, it is necessary to develop a technical solution for the placement of excess volume of rocks from drifting operations in the cavities of the mined-out longwall faces, along with the placed waste rocks from the bottom rocks undercutting.
For a detailed qualitative and quantitative analysis of the cavities and waste rocks movement, their balance has been compiled separately for the simultaneously mined seams $\mathrm{C}_{9}$, $\mathrm{C}_{10}{ }^{\mathrm{t}}, \mathrm{C}_{11}$ (Fig. 13a-c). A specificity of the technology for coal mining in the mine is that 3 coal seams are mined simultaneously, on which 4 stope faces and 8 drifting faces of extraction mine workings operate at the same time.

(a)

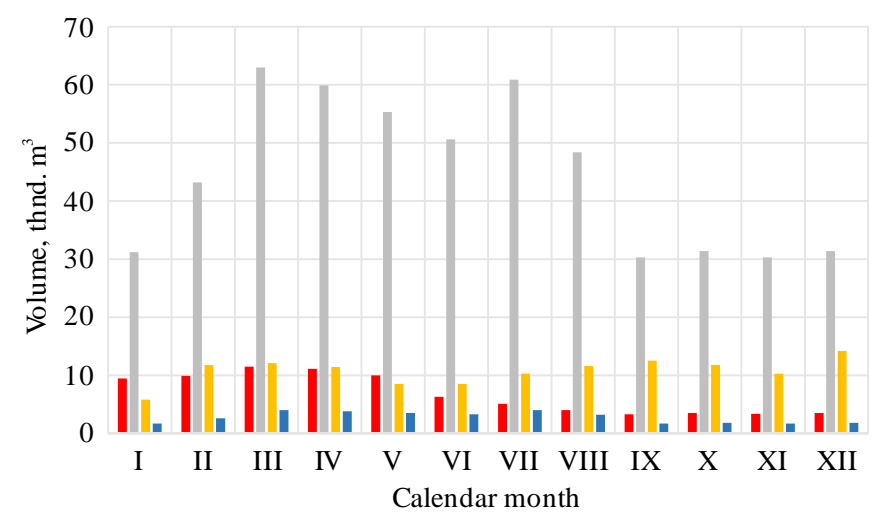

(b)

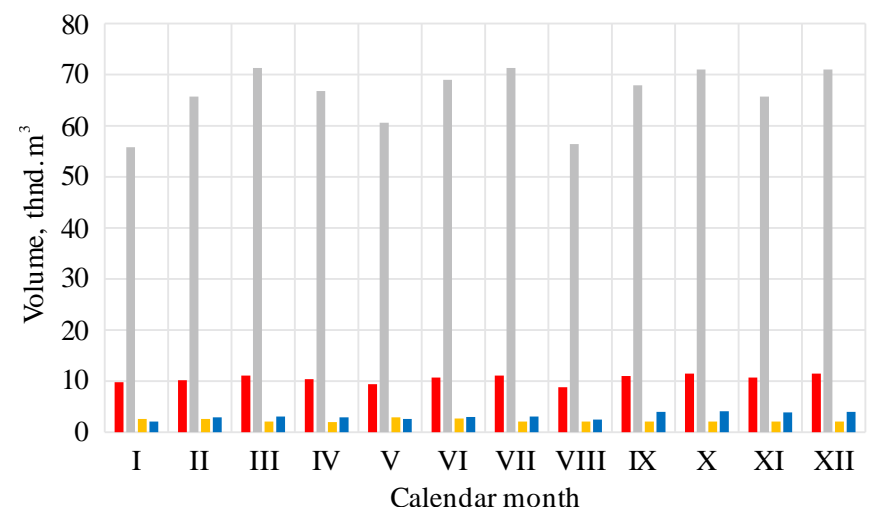

(c)

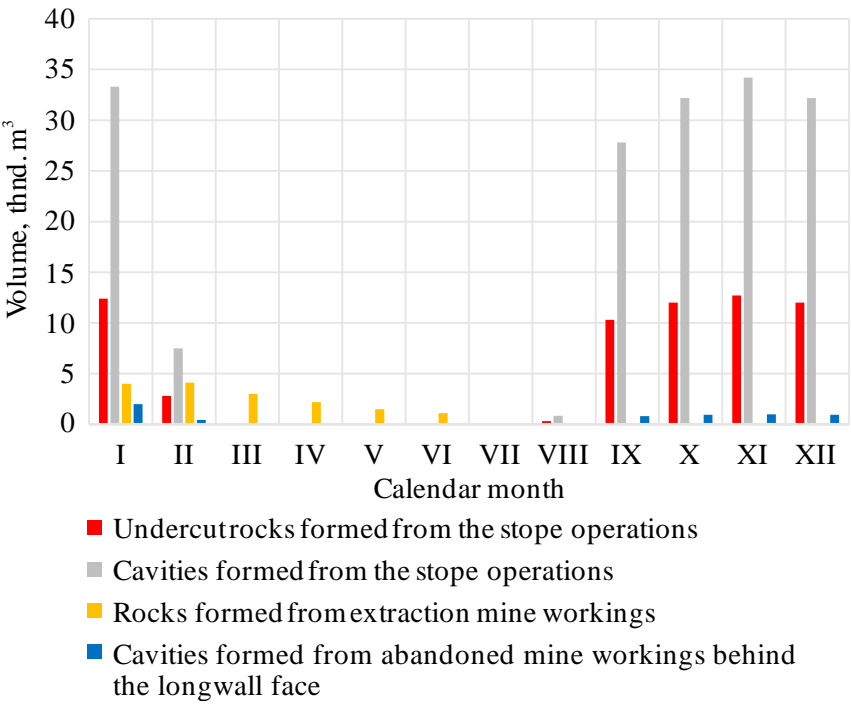

Figure 13. Dynamics of forming the volumes of rocks and cavities for a calendar month across the coal seams: (a) seam $C_{9}$; (b) seam $C_{10}{ }^{t}$; (c) seam $C_{11}$ 
Their position is constantly changing over the area of the mined seam, or the faces completely move to another seam in order to comply with the geomechanical safety associated with the influence of undermining and overworking of longwall faces. Since the research is made per a calendar year, the advance of some stope and drifting faces was started last year (transitional), and some are being advanced in the current year.

When analysing the dynamics of a change in the "rockcavities" balance (Fig. 13a), it can be seen that there is a tendency across the seam $\mathrm{C}_{9}$ of reserved volume of accumulated cavities from the stope operations, which are supposed for the placement of the waste rocks formed from undercutting. At the beginning of the year, 1 longwall face was in operation, in the middle of the year - 2 of them, at the end 1 longwall face, which is clearly observed in the dynamics of the cavities variation from the stope operations. A decrease in the volume of formed undercut rocks is noted, which is caused by an increase in the geological thickness of the seam to $1.0 \mathrm{~m}$. All the extraction mine workings were abandoned following the longwall face advance. Due to the fact that 6 extraction mine workings (from 3 longwall faces) were decommissioned during the year, and 13 extraction mine workings of different lengths were driven during the year, the volume of rock outcrop from mine workings has exceeded the volume of cavities formed when the mine workings were abandoned. In the case of the studied seam, it is possible only uninterrupted placement of undercut rocks in the cavities of the mined-out space.

The dynamics of a change in the "rock-cavities" balance (Fig. 13b) also indicates the tendency in the seam $\mathrm{C}_{10}{ }^{t}$ of reserved volume of accumulated cavities from the stope operations for the possibility of placing the rocks from bottom undercutting in them. During the year at different times, 3 longwall faces were mined on the seam, and 2 longwall faces were always in the simultaneous operation, which is explained in the graph, if compared (Fig. 13a) with the uniform formation of cavities and undercut rocks from the stope operations. It should be noted a decrease in the volume of rocks formed from mine workings, which makes it possible to place it in the cavities of abandoned extraction mine workings. This is explained by the fact that during the calendar year 3 new mine workings were conducted on 2 of 3 longwall faces mined-out this year ( 1 of them was used repeatedly). Moreover, 5 extraction mine workings have been abandoned from the 3 longwall faces operated per year. New extraction mine workings across the $\mathrm{C}_{10}{ }^{\mathrm{t}}$ seam for new longwall faces are planned to be conducted in the next calendar year.

The dynamics of a change in the "rock-cavities" balance (Fig. 13c) shows the difference in the data compared to seams $\mathrm{C}_{9}$ and $\mathrm{C}_{10}{ }^{\mathrm{t}}$, namely, there is an increase in the proportion of undercut rocks and, as a consequence of the potential completeness of filling, which is associated with a decrease in the geological thickness of the seam to $0.7 \mathrm{~m}$ and an increase in the value of rock undercutting to $0.33 \mathrm{~m}$. Stope and drifting operations were conducted unevenly across the seam. In the $2^{\text {nd }}$ month of the year, the longwall face was mined, put into operation in the previous year. In the $5^{\text {th }}$ month, the driving of the $1^{\text {st }}$ extraction drift for the new longwall face was completed (repeated use), and in the $8^{\text {th }}$ month, the mining of the new longwall face was begun. From $2^{\text {nd }}$ to $7^{\text {th }}$ months, coal was mined only in longwall faces of seams $\mathrm{C}_{9}$ and $\mathrm{C}_{10}{ }^{\mathrm{t}}$, and, therefore, the volume of rock outcrop was formed only from mine working. Next year it is planned to drive an extraction mine working for the new longwall face. The cavities formed from the stope operations allow to place the entire volume of undercut rocks, and the cavities of mine workings abandoned do not allow this. From the $3^{\text {rd }}$ to $6^{\text {th }}$ months, mine workings were not abandoned at all due to the absence of mining on the seam.

From the general analysis of graphs (Fig. 13a-c), it follows that the possibility of full rocks placement is limited by the peculiarities of scheduling the mining of reserves across the seams, drawn up for a complete cave-in technology of coal mining. The $\mathrm{C}_{10}{ }^{\mathrm{t}}$ seam is most suitable for rocks to be left in underground cavities, where there is a potential for full-fledged placement of undercut rocks in the cavities of the mined-out space, as well as rocks from abandoned mine workings. On the seam $\mathrm{C}_{9}$, there is a potential for all undercut rocks placement in the stope area and partially in the abandoned cavities. On the seam $\mathrm{C}_{11}$, there is a potential only for placement of all undercut rocks in the stope area. However, it is problematic to place in the cavities the rocks from the conducted mine workings due to the absence of abandoned mine working during the period of drifting operations.

For visual clarity, the complex relationship in time and space is graphically represented of the stope and drifting faces positions across the $\mathrm{C}_{9}$ seam, where there is their high concentration: during the calendar year, stope operations were conducted in 3 longwall faces, and in 13 drifting faces (Fig. 14).

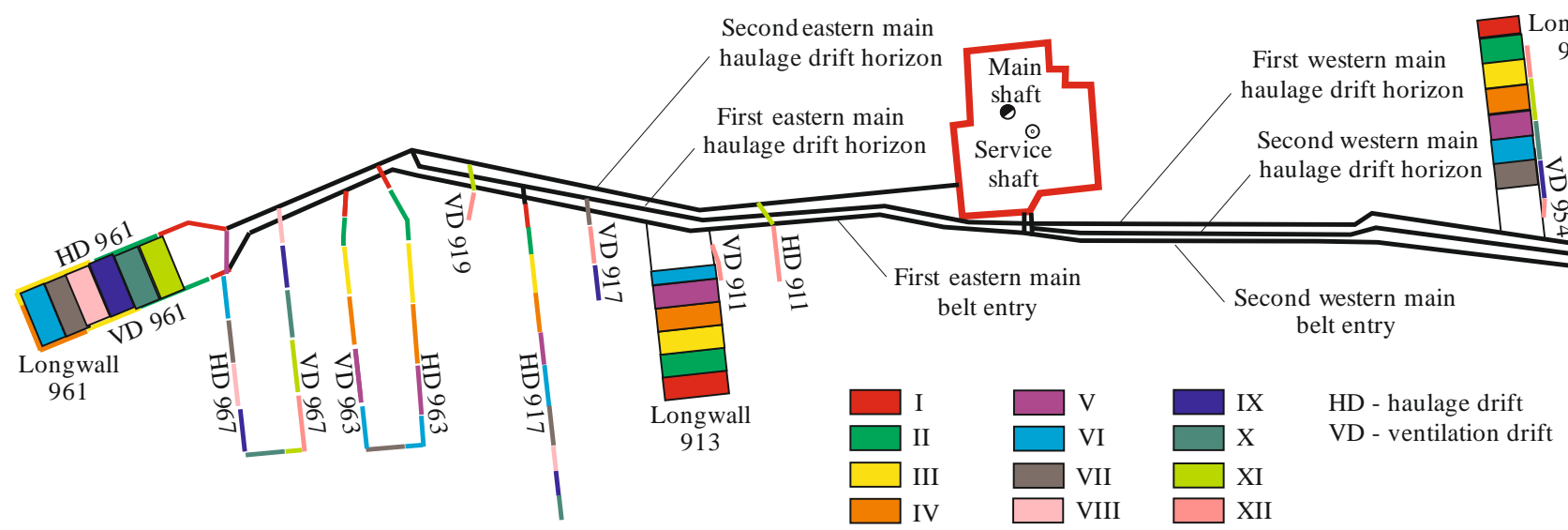

Figure 14. Schematic visualization of the relationship in time and space of the stope and drifting faces positions across the seam C9: $^{\circ}$ I - XII - calendar months of operation 
It follows from the pattern that there is a potential of leaving all the undercut rocks behind the longwall face, since the cavities of the mined-out area significantly exceed the rock volume. However, there is a problem with the placement of rocks in the abandoned mine workings. Moreover, this is connected not only with the insufficient volume of cavities of abandoned mine workings for rocks formed from the drifting, as noted in Figure 13a, but due to the dispersion of mining operations across the seam. For example, in the wing of the western mine, stope operations in the 952 longwall face and drifting operations in two 954 drifts are driven at different times and, accordingly, the rock from their operation cannot be placed in the cavities of the abandoned mine workings of the 952 longwall face. Moreover, its transportation for placement in the abandoned mine workings of the longwall faces of the eastern wing is economically unjustified and most likely the rock will be supplied to the surface through the shaft. The interaction of stope operations of the 961 longwall face and drifting operations of the 967 longwall face on placing the rocks into cavities looks promising, since, firstly, they are conducted next to each other, and secondly, at the same calendar time. It should also be noted the optimal predictive interaction of the 913 longwall face and 917 haulage road.

Thus, in terms of today's mining planning, as seen from Figure 13a-c and 14, it is problematic, without changing the plan of mining operations, to maximize the placement of waste rock from stope and drifting operations in the formed underground cavities. It is confirmed by the high concentration of mining operations and their dispersion across the seam $\mathrm{C}_{9}$, as with a large number of drifting faces, it is difficult to backfill their rocks in the cavities of the abandoned mine workings. On the other hand, as seen from Figure 13b, on a seam where virtually the same number of drifting and stope operations is conducted, an acceptable balance of formed rocks and cavities is formed. This allows to prospectively consider the placing of all rocks over the mined seam. It is recommended for increasing the efficiency of placing the rocks in underground cavities to increase the proportion of mine workings used repeatedly, which is the smallest in comparison with other mines on the basis of the use of reliable frame-roof bolting support systems of mine working fastening. Repeated use enables consistent mining of the extraction panels, thereby reducing the dispersion of drifting. It will give an ability to simultaneously conduct stope and drifting operations, which makes possible to place the rocks from drifting in the abandoned mine workings, to create a straight-through arrangement of ventilation with the possibility of additional rock flows movement through the drainage workings, as well as a number of other technical advantages.

With the existing schemes for preparing the reserves and the planning of mine workings, it is unlikely that it will be possible to completely place rocks in the mined-out space of mines. It is promising to leave in the mine only $20-30 \%$ of the entire waste rock flow supplied to the surface, and with the optimization of preparation schemes and spatial planning solutions, this indicator can be increased to $70 \%$.

\section{Conclusions}

In this paper, the movement of all waste rock flows has been studied in detail, the sources of their formation have been identified, and the balance of formed rocks and under- ground cavities has been studied in relation to the current development of mining operations in the mine field using the example of one of the Western Donbass mines operation for a calendar year. The prospects and possibilities are assessed for leaving the rocks in the underground space both for the mine as a whole and for the mined seams separately. The following results have been obtained:

1. The scientific problem has been substantiated of mining the reserves of thin coal seams in the Western Donbass, which is conditioned by the high operational ash content of the mined coal (43-50\%), the loss of a promising part of coal reserves in seams less than $0.7 \mathrm{~m}$ with the possibility of extending the operating life of mines, accumulation in rock surface dumps of more than 100 million tons of rocks over a significant area, subsidence of the earth's surface and flooding of $17.0 \mathrm{~km}^{2}$ of valuable agricultural land.

2. Based on the rank order of the Western Donbass mines, the Heroiv Cosmosu coal mine has been chosen as the object of research in terms of maximum production and ash content. An algorithm is proposed for analytical studies of determining the volume of rock outcrop in the course of stope and drifting operations, the bottom rocks ripping of mine workings, as well as the prospective underground cavities volumes for placing the formed waste rock per a calendar year.

3. It has been determined that the greatest supply of all waste rock to the surface occurs due to the stope operations with the bottom rocks undercutting - $39 \%$ and from underground mine workings preparing new coal reserves for extraction $-33 \%$, other sources in comparison have a small specific weight within the range of 2-6\%.

4. According to the nature and complexity of implementing the potential technical solutions, which are related to the rocks placement in the underground space, it is proposed to differentiate the entire waste rocks outcropping from the mine into 2 categories: difficult to dispose of and prospective for disposal. The first category should include waste rocks from the roof rocks caving and seam ash content rocks. The second category should include the rocks of undercutting in the stope faces, rocks after bottom ripping in mine workings.

5 . It has been determined that the volume of prospective waste rocks to be placed in cavities varied monthly within 22.9-44.1 thousand $\mathrm{m}^{3}$, and prospective underground cavities within 111.4-141.6 thousand $\mathrm{m}^{3}$. It has been found that underground cavities have enormous potential for placing all the waste rocks from stope, drifting and repair operations, the volume of which by 2.8-4.8 times exceeds the rock volume. It has been determined that the volume of rocks formed when conducting all extraction mine workings per a calendar year is by 2.1-3.0 times higher than the volume of cavities formed from decommissioning all the extraction mine workings following the longwall face advance. The noted imbalance is caused by the significant influence of the coefficient of rocks loosening on the increase in their volume in the destroyed state after the destruction of the face by the tunnelling machine.

6 . It has been determined that the possibility of performing full-fledged placement of rocks is limited by the scheduling peculiarities of mining the reserves over seams, which are made for the technology of complete cave-in mining of coal. The $\mathrm{C}_{10}{ }^{t}$ seam is the most suitable for rocks to be left in underground cavities, where there is a potential for full-fledged placing the rocks of undercutting in the cavities of the mined-out space, as well as rocks from abandoned mine workings. 
7. It is recommended to intensively develop a program for repeated use of extraction mine workings, which will allow: to consistently mine the extraction panels, thereby reducing the dispersion of drifting; to simultaneously conduct stope and drifting operations, which will make it possible to place the rocks from drifting in the abandoned mine workings; to create a straight-through arrangement of ventilation with the possibility of additional rock flows movement through the drainage workings, as well as a number of other technical advantages.

8. It is noted that with the existing schemes for preparing the reserves and the planning of mine workings, it is promising to leave in the mine only $20-30 \%$ of the entire waste rock flow supplied to the surface. However, with the optimization of preparation schemes and spatial planning solutions, it is possible to increase this indicator to $70 \%$ by the designing of special backfilling mine workings or giving such a function to existing mine workings.

\section{Acknowledgements}

The results of the work have been obtained within the framework of the research-and-development work "Development of advanced technologies for the complete mining of steam coal with the accumulation of waste rocks in the underground space" (No. 0120U101099). The authors are grateful to the specialists of PJSC "DTEK Pavlohradvuhillia" for the information on the mine provided for research-andtechnology analysis.

\section{References}

[1] Teichmann, F., Falker, M.-C., \& Sergi, B.S. (2020). Extractive industries, corruption and potential solutions. The case of Ukraine. Resources Poli$c y$, (69), 101844. https://doi.org/10.1016/j.resourpol.2020.101844

[2] Kostetska, K., Laurinaitis, M., Savenko, I., Sedikova, I., \& Sylenko, S. (2020). Mining management based on inclusive economic approach. E3S Web of Conferences, (201), 01009. https://doi.org/10.1051/e3sconf/202020101009

[3] Horoshkova, L., Volkov, V., \& Khlobystov, I. (2019). Prognostic model of mineral resources development in Ukraine. Monitoring, (2019), 1-5. https://doi.org/10.3997/2214-4609.201903171

[4] Kwilinski, A., Zaloznova, Y., Trushkina, N., \& Rynkevych, N. (2020). Organizational and methodological support for Ukrainian coal enterprises marketing activity improvement. E3S Web of Conferences, (168), 00031. https://doi.org/10.1051/e3sconf/202016800031

[5] Shatokha, V. (2017). Post-Soviet issues and sustainability of iron and steel industry in Eastern Europe. Mineral Processing and Extractive Metallurgy, 126(1-2), 62-69. https://doi.org/10.1080/03719553.2016.1251750

[6] Shustov, O.O., Haddad, J.S., Adamchuk, A.A., Rastsvietaiev, V.O., \& Cherniaiev, O.V. (2019). Improving the construction of mechanized complexes for reloading points while developing deep open pits. Journal of Mining Science, 55(6), 946-953. https://doi.org/10.1134/s1062739119066332

[7] IEA. (2019). Coal Information 2019. Paris, France. Retrieved from https://www.iea.org/reports/coal-information-2019

[8] Spencer, D. (2019). BP statistical review of world energy statistical review of world. Review of World Energy, (68), 1-69.

[9] Cornot-Gandolphe, S. (2019). Status of global coal markets and major demand trends in key regions. Paris, France: Ifri.

[10] State Statistics Service of Ukraine. (2020). Retrieved from http://www.ukrstat.gov.ua/

[11] Wang, Q., Song, X., \& Liu, Y. (2020). China's coal consumption in a globalizing world: Insights from multi-regional input-output and structural decomposition analysis. Science of The Total Environment, (711), 134790. https://doi.org/10.1016/j.scitotenv.2019.134790

[12] Kamiński, P.K., \& Kamiński, J. (2020). Coal demand and environmental regulations: A case study of the Polish power sector. Energies, 13(6), 1521. https://doi.org/10.3390/en13061521

[13] Sribna, Y., Trokhymets, O., Nosatov, I., \& Kriukova, I. (2019). The globalization of the world coal market - contradictions and trends. E3S Web of Conferences, (123), 01044. https://doi.org/10.1051/e3sconf/201912301044
[14] Bondarenko, V.I., \& Sai, K.S. (2018). Process pattern of heterogeneous gas hydrate deposits dissociation. Naukovyi Visnyk Natsionalnoho Hirnychoho Universytetu, (2), 21-28. https://doi.org/10.29202/nvngu/2018-2/4

[15] Ganushevych, K., Sai, K., \& Korotkova, A. (2014). Creation of gas hydrates from mine methane. Progressive Technologies of Coal, Coalbed Methane, and Ores Mining, 505-509. https://doi.org/10.1201/b17547-85

[16] Havrysh, V., Kalinichenko, A., Mentel, G., \& Olejarz, T. (2020). Commercial biogas plants: lessons for Ukraine. Energies, 13(10), 2668. https://doi.org/10.3390/en13102668

[17] Malashkevych, D., Poimanov, S., Shypunov, S., \& Yerisov, M. (2020). Comprehensive assessment of the mined coal quality and mining conditions in the Western Donbas mines. E3S Web of Conferences, (201), 01013. https://doi.org/10.1051/e3sconf/202020101013

[18] Astafiev, D., Shapovalov, Y., Kaminski, P., \& Herezy, L. (2014). Analysis of longwall equipment for thin seams mining in conditions of Polish and Ukrainian mines. Progressive Technologies of Coal, Coalbed Methane, and Ores Mining, 287-292. https://doi.org/10.1201/b17547-50

[19] Pavlenko, I., Salli, V., Bondarenko, V., Dychkovskiy, R., \& Piwniak, G. (2007). Limits to economic viability of extraction of thin coal seams in Ukraine. Technical, Technological and Economical Aspects of ThinSeams Coal Mining, International Mining Forum, 129-132. https://doi.org/10.1201/noe0415436700.ch16

[20] Li, H., Zha, J., Guo, G., Zheng, N., \& Gong, Y. (2020). Improvement of resource recovery rate for underground coal gasification through the gasifier size management. Journal of Cleaner Production, (259), 120911. https://doi.org/10.1016/j.jclepro.2020.120911

[21] Petlovanyi, M., Lozynskyi, V., Saik, P., \& Sai, K. (2019). Predicting the producing well stability in the place of its curving at the underground coal seams gasification. E3S Web of Conferences, (123), 01019. https://doi.org/10.1051/e3sconf/201912301019

[22] Li, B., Yan, H., Zhang, J., \& Zhou, N. (2020). Compaction property prediction of mixed gangue backfill materials using hybrid intelligence models: A new approach. Construction and Building Materials, (247), 118633. https://doi.org/10.1016/j.conbuildmat.2020.118633

[23] Li, M., Zhang, J., Li, A., \& Zhou, N. (2020). Reutilisation of coal gangue and fly ash as underground backfill materials for surface subsidence control. Journal of Cleaner Production, (254), 120113. https://doi.org/10.1016/j.jclepro.2020.120113

[24] Wang, F., Jiang, B., Chen, S., \& Ren, M. (2019). Surface collapse control under thick unconsolidated layers by backfilling strip mining in coal mines. International Journal of Rock Mechanics and Mining Sciences, (113), 268-277. https://doi.org/10.1016/j.ijrmms.2018.11.006

[25] Petlovanyi, M., Malashkevych, D., \& Sai, K. (2020). The new approach to creating progressive and low-waste mining technology for thin coal seams. Journal of Geology, Geography and Geoecology. Article in press.

[26] Kuzmenko, O., Petlyovanyy, M., \& Heylo, A. (2014). Application of fine-grained binding materials in technology of hardening backfill construction. Progressive Technologies of Coal, Coalbed Methane, and Ores Mining, 465-469. https://doi.org/10.1201/b17547-79

[27] Khomenko, O., Kononenko, M., \& Petlyovanyy, M. (2014). Investigation of stress-strain state of rock massif around the secondary chambers. Progressive Technologies of Coal, Coalbed Methane, and Ores Mining, 241-245. https://doi.org/10.1201/b17547-43

[28] Sun, Q., Zhang, J., Huang, Y., \& Yin, W. (2019). Failure mechanism and deformation characteristics of gob-side entry retaining in solid backfill mining: A case study. Natural Resources Research, 29(4), 2513-2527. https://doi.org/10.1007/s11053-019-09584-4

[29] Bubnova, O. (2019). Prediction of changes in the state of the geological environment in the mining region. E3S Web of Conferences, (109), 00009. https://doi.org/10.1051/e3sconf/201910900009

[30] Bosak, P., Popovych, V., Stepova, K., \& Dudyn, R. (2020). Environmental impact and toxicological properties of mine dumps of the Lviv-Volyn coal basin. News of National Academy of Sciences of the Republic of Kazakhstan, 2(440), 48-54. https://doi.org/10.32014/2020.2518-170x.30

[31] Petlovanyi, M.V., \& Medianyk, V.Y. (2018). Assessment of coal mine waste dumps development priority. Naukovyi Visnyk Natsionalnoho Hirnychoho Universytetu, (4), 28-35. https://doi.org/10.29202/nvngu/2018-4/3

[32] Khorolskyi, A., Hrinov, V., \& Kaliushenko, O. (2019). Network models for searching for optimal economic and environmental strategies for field development. Procedia Environmental Science, Engineering and Management, 6(3), 463-471.

[33] Petlovanyi, M., \& Mamaikin, O. (2019). Assessment of an expediency of binder material mechanical activation in cemented rockfill. ARPN Journal of Engineering and Applied Sciences, 14(20), 3492-3503.

[34] Jiang, H., Fall, M., Li, Y., \& Han, J. (2019). An experimental study on compressive behaviour of cemented rockfill. Construction and Building Materials, (213), 10-19. https://doi.org/10.1016/j.conbuildmat.2019.04.061 
[35] Gorova, A., Pavlychenko, A., Kulyna, S., \& Shkremetko, O. (2015). Environmental aspects of waste management on coal mining enterprises New Developments in Mining Engineering 2015: Theoretical and Practical Solutions of Mineral Resources Mining, 179-184 https://doi.org/10.1201/b19901-33

[36] Popovych, V., Stepova, K., Voloshchyshyn, A., \& Bosak, P. (2019). Physico-chemical properties of soils in Lviv Volyn coal basin area. E3S Web of Conferences, (105), 02002. https://doi.org/10.1051/e3sconf/201910502002

[37] Petlovanyi, M.V., Lozynskyi, V.H., Saik, P.B., \& Sai, K.S. (2018) Modern experience of low-coal seams underground mining in Ukraine. International Journal of Mining Science and Technology, 28(6), 917-923. https://doi.org/10.1016/j.ijmst.2018.05.014

[38] Zhang, Z., Liu, Y., Hu, Q., Zhang, Z., Wang, L., Liu, X., \& Xia, X (2020). Multi-information online detection of coal quality based on machine vision. Powder Technology, (374), 250-262. https://doi.org/10.1016/j.powtec.2020.07.040

[39] Pulungan, L., \& Arbianto, V. (2020). Coal handling quality from pits to stockpiles to market specifications. IOP Conference Series: Materials Science and Engineering, (830), 042039. https://doi.org/10.1088/1757899x/830/4/042039

[40] Petlovanyi, M., Ruskykh, V., Zubko, S., \& Medianyk, V. (2020). Dependence of the mined ores quality on the geological structure and properties of the hanging wall rocks. E3S Web of Conferences, (201), 01027. https://doi.org/10.1051/e3sconf/202020101027

[41] Khanal, M., \& Hodgkinson, J.H. (2021). Subsidence prediction versus observation in Australia: A short comment. Environmental Impact Assessment Review, (86), 106479. https://doi.org/10.1016/j.eiar.2020.106479

[42] Zhao, J., \& Konietzky, H. (2020). Numerical analysis and prediction of ground surface movement induced by coal mining and subsequent groundwater flooding. International Journal of Coal Geology, (229), 103565. https://doi.org/10.1016/j.coal.2020.103565

[43] Regional report on the state of the environment in the Dnipropetrovsk region for 2019. (2019). Dnipro, Ukraine: Department of Ecology and Natural Resources of Dnipropetrovsk Regional State Administration.

[44] Kotlyar, V., Yavruyan, K., Gaishun, E., \& Teryokhina, Y. (2018). Comprehensive approach to the processing of east Donbass spoil tip. 2018 IEEE International Conference "Management of Municipal Waste as an Important Factor of Sustainable Urban Development" (WASTE), 18290826. https://doi.org/10.1109/waste.2018.8554158
[45] Kovalevs'ka, I., Symanovych, G., \& Fomychov, V. (2013). Research of stress-strain state of cracked coal-containing massif near-theworking area using finite elements technique. Annual ScientificTechnical Collection - Mining of Mineral Deposits 2013, 159-164. https://doi.org/10.1201/b16354-27

[46] Shashenko, O., Shapoval, V., Khalymendyk, O., Andrieiev, V., Arbuzov, M., Hubar, O., \& Markul, R. (2019). Features of the nonlinear calculation of the stress-strain state of the "rock massif - excavation support" system taking into account destruction. Transport Means 2019: Proceedings of the $23^{\text {rd }}$ International Scientific Conference, (3), 1356-1363.

[47] Solodyankin, A.V., \& Dudka, I.V. (2016). Issledovanie vliyaniya ochistnykh rabot na ustoychivost' uchastkovykh vyrabotok v usloviyakh OP "Shakhta Partizanskaya" GP "Antratsit". Visnyk Kryvoriz'koho Natsional'noho Universytetu, (41), 102-107.

[48] Khalimendik, Yu.M., Baryshnikov, A.S., Bruy, A.V., Voronin, S.A., \& Efremov, A.V. (2014). Effektivnost' primeneniya kanatnykh ankerov v usloviyakh slabykh bokovykh porod. Forum Hirnykiv, (2), 171-182.

[49] Egorov, P.V., Bober, E.A., Kuznetsov, Yu.N., Kos'minov, E.A., Reshetov, S.E., \& Krasyuk, N.N. (2006). Osnovy gornogo dela. Moskva, Rossiya: Izdatelstvo MGGU.

[50] Byzylo, V., Koshka, O., Poymanov, S., \& Malashkevych, D. (2015). Resource-saving technology of selective mining with gob backfilling. New Developments in Mining Engineering 2015: Theoretical and Practical Solutions of Mineral Resources Mining, 485-491. https://doi.org/10.1201/b19901-84

[51] Stupnik, M., Kolosov, V., Pysmennyi, S., \& Kovbyk, K. (2019). Selective mining of complex stuctured ore deposits by open stope systems. E3S Web of Conferences, (123), 01007. https://doi:10.1051/e3sconf/201912301007

[52] Emad, M.Z., Vennes, I., Mitri, H., \& Kelly, C. (2014). Backfill practices for sublevel stoping system. Mine Planning and Equipment Selection, 391-402. https://doi.org/10.1007/978-3-319-02678-7_38

[53] Petlovanyi, M. (2016). Influence of configuration chambers on the formation of stress in multi-modulus mass. Mining of Mineral Deposits, 10(2), 48-54. https://doi.org/10.15407/mining10.02.048

[54] Petlovanyi, M., Lozynskyi, V., Zubko, S., Saik, P., \& Sai, K. (2019). The influence of geology and ore deposit occurrence conditions on dilution indicators of extracted reserves. Rudarsko Geolosko Naftni Zbornik, 34(1), 83-91. https://doi.org/10.17794/rgn.2019.1.8

\section{Дослідження балансу утворення порід і підземних пустот у технологічній схемі вугільної шахти при розробці малопотужних пластів}

\section{М. Петльований, Д. Малашкевич, К. Сай, С. Зубко}

Мета. Дослідження руху потоків пустих порід у технологічній системі вугільної шахти та визначення балансу утворених порід і підземних пустот у взаємозв'язку з поточним розвитком гірничих робіт для оцінки можливостей залишення порід у підземному просторі.

Методика. Як об’єкт дослідження було обрано вугільну шахту на підставі ранжирування шахт Західного Донбасу за максимальним видобутком і зольністю. Запропоновано алгоритм аналітичних досліджень визначення виходу порід при веденні очисних, прохідницьких і ремонтних робіт, а також перспективних обсягів підземних пустот для розміщення утворених пустих порід за календарний рік. Алгоритм грунтувався на фактичному положенні гірничих робіт і показниках очисних та прохідницьких вибоїв шахти, а також досягнутих сучасних гірничотехнічних параметрах розробки вугільних пластів.

Результати. Встановлено, що основне надходження пустих порід на поверхню відбувається внаслідок виконання очисних робіт 3 присіканням порід (39\%) і проведення підземних гірничих виробок (33\%). Запропоновано всі пусті породи, що виходять 3 шахти, розділити на 2 категорії: ті, що важко утилізуються, та перспективні до утилізації. Встановлено, що підземні пустоти мають колосальний потенціал до розміщення всіх пустих порід, обсяг яких в 2.8-4.8 рази перевершує обсяг порід. Визначено, що по пласту $\mathrm{C}_{10}{ }^{\text {в }}$ формується найбільш раціональний баланс формованих порід і пустот для їх залишення в шахті. Встановлено, що повноцінне розміщення порід обмежене особливостями календарного планування відпрацювання запасів по пластах, які складені під технологію видобутку вугілля з повним обваленням.

Наукова новизна. Вперше для однієї з шахт Західного Донбасу визначено баланс формованих пустих порід і потенційних підземних пустот, що динамічно змінюються у часі та просторі.

Практична значимість. Отримані результати корисні для проектування нових просторово-планувальних рішень 3 оптимального розвитку гірничих робіт з максимально можливим розміщенням порід у підземному просторі шахт.

Ключові слова: порожні породи, зольність, підземні пустоти, присікання, очисний та прохідницький вибій, закладка, календарне планування

\section{Исследование баланса образования пород и подземных пустот в технологической схеме угольной шахты при разработке маломощных пластов}

\section{М. Петлёваный, Д. Малашкевич, Е. Сай, С. Зубко}

Цель. Исследование движения потоков пустых пород в технологической системе угольной шахты и определение баланса образованных пород и подземных пустот во взаимосвязи с текущим развитием горных работ для оценки возможностей оставления пород в подземном пространстве.

Методика. В качестве объекта исследования была выбрана угольная шахта на основании ранжирования шахт Западного Донбасса по максимальной добыче и зольности. Предложен алгоритм аналитических исследований определения выхода пород при 
ведении очистных, проходческих и ремонтных работ, а также перспективных объемов подземных пустот для размещения образованных пустых пород за календарный год. Алгоритм основывался на фактическом положении горных работ и показателях очистных и проходческих забоев шахты, а также достигнутых современных горнотехнических параметрах разработки угольных пластов.

Результаты. Установлено, что основное поступление пустых пород на поверхность происходит вследствие выполнения очистных работ с присечкой пород (39\%) и проведения подземных горных выработок (33\%). Предложено все выходящие из шахты пустые породы разграничить на 2 категории: трудно утилизируемые и перспективные к утилизации. Установлено, что подземные пустоты имеют колоссальный потенциал к размещению всех пустых пород, объем которых в 2.8-4.8 раза превосходит объем пород. Определено, что по пласту $\mathrm{C}_{10}{ }^{\mathrm{B}}$ формируется наиболее рациональный баланс формируемых пород и пустот для их оставления в шахте. Установлено, что полноценное размещение пород ограничено особенностями календарного планирования отработки запасов по пластам, которые составлены под технологию добычи угля с полным обрушением.

Научная новизна. Впервые для одной из шахт Западного Донбасса определен баланс формируемых пустых пород и потенциальных подземных пустот, динамически изменяющихся во времени и пространстве.

Практическая значимость. Полученные результаты полезны для проектирования новых пространственно-планировочных решений по оптимальному развитию горных работ с максимально возможным размещением пород в подземном пространстве шахт.

Ключевые слова: пустые породы, зольность, подземные пустоты, присечка, очистной и проходческий забой, закладка, календарное планирование

\section{Article info}

Received: 28 April 2020

Accepted: 9 November 2020

Available online: 7 December 2020 